\title{
Development of Microalgae-based Biofuels as a Viable Green Energy Source: Challenges and Future Perspectives
}

\author{
Judy Mathushika ${ }^{1 \mathbb{D}}$, Chandima Gomes $2, * \mathbb{( D )}$ \\ 1 Department of Plant Science, University of Colombo, Sri Lanka - mathushikaj@ gmail.com_(J.M.); \\ 2 School of Electrical and Information Engineering, University of the Witwatersrand, South Africa - \\ chandima.gomes@wits.ac.za (C.G.); \\ * Correspondence: chandima.gomes@wits.ac.za (C.G.);
}

Scopus Author ID 57201335285

Received: 2.04.2021; Revised: 22.05.2021; Accepted: 28.05.2021; Published: 13.08.2021

\begin{abstract}
This paper presents a comprehensive account of the harvesting and processing technologies of microalgae and their applications in developing biofuels such as biodiesel, ethanol, biogas, syngas, and hydrogen. Microalgae have been reflected as an environmental pollution controlling agent due to their faster growth rate, making them a viable alternative to replace the current uses of non-renewable sources. The significantly large volumes of microalgae culture required for bio products are highlighted as a major concern of the complexity at the harvesting stage. At present, there are hardly any single methods that could generally be applied for processing the broad range of microalgae species with varying characteristics. Improvements are also required to effectively minimize the energy and cost required for the microalgae processing methods to be applicable at a commercial scale. By improving the techniques used at the harvesting stage, the costs associated with further processing steps to produce microalgae-based bio products and biofuels could be reduced. Future studies should also focus on identifying better algae strains that produce a high yield of good quality biofuel to economically viable algae biofuel.
\end{abstract}

Keywords: microalgae; harvesting; energy applications; processing; biofuel.

(C) 2021 by the authors. This article is an open-access article distributed under the terms and conditions of the Creative Commons Attribution (CC BY) license (https://creativecommons.org/licenses/by/4.0/).

\section{Introduction}

Algae are a community of photosynthetic autotrophs usually found in different kinds of water bodies like lakes, rivers, and seas. Microalgae are single-cell microorganisms within the algae community that exist in both marine and fresh water habitats. Regardless of the lack of composite structures and organs relative to their plant equivalents, due to the existence of pigments involved in photosynthesis, including chlorophylls in their cells, microalgae can conduct photosynthesis utilizing sunlight, carbon dioxide, and water [1]. As microalgae are microscopic species found within the aqatic environment and in terrestrial environments, they depict a large number of organisms that can survive in diverse ecosystems. Under varying sorts of metabolic circumstances, including autotrophic, heterotrophic, photoheterotrophic, and mixotrophic, microalgae can grow faster and primarily demand three major growth components,: sunlight, water and carbon [2]. Since geography is a crucial determining factor in the determination of microalgae strains that can be used to produce biomass, tropical or subtropical regions with an ample year-round supply of solar radiation and saline water (either from the sea or as groundwater) are typically the best for algae mass cultivation [3]. So, this is an added advantage to the tropical countries in using the microalgae as raw material [4]. 
The worldwide increase in energy demand from residential and commercial spaces has recently been followed by a simultaneous increase in the use of fossil fuels. Global demand for fuel energy is constantly rising with the rapidly growing world population. The widespread use of fossil fuels globally results in their destruction and would make them closer to depletion because of their untenable and non-renewable existence [5]. A massive amount of fossil fuel is still available at substantial expense, but it is steadily inching towards depletion due to the overexploitation of fuel supplies. In addition, the unsustainable combustion of fossil fuels has contributed to raised greenhouse gas emissions (GHGs) and has thus resulted in global warming. Too much fossil fuel burning can also contribute to particulate matter, volatile organic compounds, and other air pollutants such as $\mathrm{NOx}, \mathrm{SOx}, \mathrm{CO}_{2}, \mathrm{CO}$, etc. Therefore, since it is sustainable and can significantly reduce GHG emissions by photosynthesis, biomass may be viewed as a desirable substitute for fossil fuels. Mostly in ecological, economic, and social fields, the huge-scale production of biomass energy will lead to more sustainable advantages. As an alternative to fossil fuels, biofuels are now an increasing opportunity worldwide [6].

High microalgae photosynthesis effectiveness combined with the potential to assemble a significant percentage of bio-products in their cells makes them a perfect option for industrial raw materials [7]. Since the 1970s, microalgae have been explored as feedstock for the generation of biodiesel due to their extensive abundance and greater oil yields than traditional terrestrial plants [8]. Consequently, the current emphasis is on microalgae as a promising raw material for bioenergy production as feedstock for the compensation and juggling of the everincreasing market for biofuel production. Research on harvesting and processing microalgae and their applications in developing eceomically viable green products, such as biofuels, has been done comprehensively in the last few years. However, no work in the literature has adequately addressed these research developments with respect to the processes and applications of microalgae-based bio-products and their significance in many countries. This review is an effort to fulfill this research void, which will immensely assist future developments and improvisations in overcoming the existing challenges in the scientific frontiers.

\section{Information Analysis}

\subsection{Types of algae and their metabolism.}

Algae is known as plant-like species, which are generally photosynthetic and aquatic but do not have true roots, branches, leaves, and primary reproductive structures. Algae are commonly known as Phaeophyta (brown algae), Chlorophyta (green algae), and Rhodophyta (red algae) and are featured as microalgae or macroalgae by size. More than one million organisms are included collectively [9].

Macroalgae (seaweed) are multicellular, higher in dimension, and observable to the naked eye, whereas microalgae are unicellular, microscopic, and can be prokaryotic, cyanobacteria-like (Chloroxybacteria), or eukaryotic, green-algae-like (Chlorophyta) [5]. They are uncomplicated, single cellular or multicellular photosynthetic species that use sunlight to fix and transform atmospheric $\mathrm{CO}_{2}$ into biomass.

Prokaryotic cyanobacteria, eukaryotic microalgae, and diatoms are among the most frequently examined microalgae for biofuel and valuable chemical processing in academia and business [10].

The microalgae community has the ability to live in both fresh water and marine environments. In regard to microscopical semblance, freshwater algae can be classified into 10 
main divisions (phyla) (Table 1). Some other phyla- Raphidophyta, Haptophyta, Eustigmatophyta, Prasinophyta, and Glaucophyta are also accessible in addition to these classes. Whereas these subsidiary phyla have taxonomic and phylogenetic importance, they have minimal influence on the ecosystem of freshwater [7].

The common name for marine algae is seaweed. Seaweeds are not plants at all, but they can resemble plants that survive underwater, developing in more than 150 feet in length in some instances. The marine algae generally fall into three distinct groups: red, green, and brown algae from the Protista kingdom. The complete classification of algae is given in Table 2. Whereas algae are not plants, they do match some primary features with them. Marine algae, including plants, use chlorophyll for photosynthesis. Seaweeds also have cell walls that are similar to plants. Moreover, seaweeds do not have any root or internal vascular structures, unlike plants, nor do they contain seeds or flowers, both of which should be categorized as plants [11].

Table 1. Prime classifications of freshwater algae [7].

\begin{tabular}{|c|c|c|c|c|c|c|c|c|}
\hline Algal division & Phylum & Examples & $\begin{array}{l}\text { Single } \\
\text { cellular }\end{array}$ & Multicellular & Microscopic & Filamentous & $\begin{array}{c}\text { Visible } \\
\text { to } \\
\text { naked } \\
\text { eye }\end{array}$ & Colonial \\
\hline Brown algae & Phaeophyta & $\begin{array}{l}\text { Pleurocladia } \\
\text { Heribaudiella }\end{array}$ & & $\sqrt{ }$ & & & $\sqrt{ }$ & \\
\hline Red algae & Rhodophyta & $\begin{array}{l}\text { Batrachospermum } \\
\text { Bangia }\end{array}$ & $\sqrt{ }$ & & $\sqrt{ }$ & & $\sqrt{ }$ & $\sqrt{ }$ \\
\hline Chrysophytes & Chrysophyta & $\begin{array}{l}\text { Mallomonas } \\
\text { Dinobryon }\end{array}$ & $\sqrt{ }$ & & $\sqrt{ }$ & & & $\sqrt{ }$ \\
\hline $\begin{array}{l}\text { Yellow-green } \\
\text { algae }\end{array}$ & Xanthophyta & $\begin{array}{l}\text { Ophiocytium } \\
\text { Vaucheria }\end{array}$ & $\sqrt{ }$ & & $\sqrt{ }$ & $\sqrt{ }$ & & \\
\hline Green algae & Chlorophyta & $\begin{array}{l}\text { Chlamydomonas } \\
\text { Cladophora }\end{array}$ & $\sqrt{ }$ & & $\sqrt{ }$ & $\sqrt{ }$ & $\sqrt{ }$ & $\sqrt{ }$ \\
\hline $\begin{array}{l}\text { Blue-green } \\
\text { algae }\end{array}$ & Cyanophyta & $\begin{array}{l}\text { Synechocystis } \\
\text { Microcystis }\end{array}$ & & & $\sqrt{ }$ & & $\sqrt{ }$ & $\sqrt{ }$ \\
\hline Euglenoids & Euglenophyta & $\begin{array}{l}\text { Euglena } \\
\text { Colacium }\end{array}$ & $\sqrt{ }$ & & $\sqrt{ }$ & & & \\
\hline Cryptomonads & Cryptophyta & $\begin{array}{l}\text { Rhodomonas } \\
\text { Cryptomonas }\end{array}$ & $\sqrt{ }$ & & $\sqrt{ }$ & & & \\
\hline Diatoms & Bacillariophyta & $\begin{array}{l}\text { Stephanodiscus } \\
\text { Aulacoseira }\end{array}$ & $\sqrt{ }$ & & $\sqrt{ }$ & $\sqrt{ }$ & & $\sqrt{ }$ \\
\hline Dinoflagellates & Dinophyta & $\begin{array}{l}\text { Ceratium } \\
\text { Peridinium }\end{array}$ & $\sqrt{ }$ & & $\sqrt{ }$ & & & \\
\hline
\end{tabular}

Table 2. Classification of marine algae [12].

\begin{tabular}{|c|c|c|}
\hline Algal class & Order & Original species \\
\hline Rhodophyta & $\begin{array}{l}\text { Bangiales } \\
\text { Gigartinales } \\
\text { Palmariales }\end{array}$ & $\begin{array}{l}\text { Porphyra dioica J.Brodie \& L.M.Irvine, } 1997 \\
\text { Ulva purpurea } \text { Roth, } 1797 \\
\text { Porphyra umbilicalis Kützing, } 1843 \\
\text { Chondrus crispus } \text { Stackhouse, } 1797 \\
\text { Fucus stellatus Stackhouse, } 1796 \\
\text { Fucus } \text { lumbricalis } \text { Hudson, } 1762 \\
\text { Fucus palmatus Linnaeus, } 1753\end{array}$ \\
\hline Chlorophyta & $\begin{array}{l}\text { Ulvales } \\
\text { Cladophorales }\end{array}$ & $\begin{array}{l}\text { Ulva intestinalis } f . \text { filiformis P.Crouan \& H.Crouan } \\
\text { Ulva lactuca Linnaeus, } 1753 \\
\text { Conferva rupestris Linnaeus, } 1753\end{array}$ \\
\hline Phaeophyceae & $\begin{array}{l}\text { Fucales } \\
\text { Laminariales } \\
\text { Ectocarpales }\end{array}$ & $\begin{array}{l}\text { Fucus serratus var. lacinatus Greville, } 1890 \\
\text { Fucus vesiculosus var. angustifolius C.Agardh, } 1817 \\
\text { Fucus canaliculatus Linnaeus, } 1767 \\
\text { Fucus esculentus Linnaeus, } 1767 \\
\text { Fucus digitatus Hudson, } 1762 \\
\text { Fucus flagelliformis O.F.Müller, } 1775\end{array}$ \\
\hline
\end{tabular}


As opportunities for novel metabolites and biotechnologically valuable genes, marine microalgae, the biggest primary bio-mass, have been seizing interest. A large number of microalgae are there in the mixed marine climate. There are at least 30,000 species of microalgae that are recognized. Microalgae are categorized mainly as single cellular photosynthetic cells, even though some composite associations give larger structures to colonies. This is rather a heterogeneous group that involves bacteria-like prokaryotic organisms (cyanobacteria or blue-green algae) and eukaryotic species like diatoms. Blue-green species are too high in number and possibly not deeply investigated [7].

Microalgae are able to discover their resource management conditions and their effective use. In general, photosynthesis requires a satisfactory amount of carbon source and light for the progression of microalgae. Not just the organic source of carbon (e.g., protein, fat, and sugar), but also vitamins, nitrogen, phosphorus, and salts are needed to grow microalgae. The balancing act between controlling variables (molecular oxygen, $\mathrm{CO}_{2}$, light intensity, temperature, $\mathrm{pH}$ level, and product elimination and by-product elimination) is also vitally important [13].

Microalgae have the potential to grow under several sorts of metabolic conditions, including autotrophic, heterotrophic, photoheterotrophic, and mixotrophic. Some examples of strains that can be able to nurture under photoautotrophic, heterotrophic, and mixotrophic circumstances are Arthrospira platensis, Chlorella vulgaris, and Haematococcuspluvialis. For example, while other microalgal strains may grow whichever photoautotrophically, heterotrophically, or photoheterotrophically, Scenedesmusacutus and Selenastrum capricornutum [14]. Moreover, the metabolism of algae differs based on the adjustment in $\mathrm{pH}$, which relies on the stoichiometry of the microalgae growth. The metabolic switch in microalgae occurs as a consequence of changes in environmental factors [2].

\subsection{Algae-based bio-fuels.}

Algal-based fuels have 10\%-45\% oxygen levels and reduced sulfur releasing levels, while petroleum-based fuels do not show greater sulfur releasing levels of oxygen. Biofuels are non-polluting, locally accessible, cost-effective, renewable sources of sustainable and reliable fuel. Microalgae fuels based on algae are eco-friendly, non-toxic, and highly capable of global $\mathrm{CO}_{2}$ fixation. It has been documented that $1.83 \mathrm{~kg}$ of $\mathrm{CO}_{2}$ can be fixed by $1 \mathrm{~kg}$ of algal biomass, and some organisms use $\mathrm{SO}_{\mathrm{x}}$ and $\mathrm{NO}_{\mathrm{x}}$ along with $\mathrm{CO}_{2}$ as nutrient flow. 50 percent of the dry weight of algal biomass is $\mathrm{CO}_{2}$ [5].

Biomass selection and production is a censorious, cost-deciding stage in developing biofuels to adjust and optimize energy framework and cost. Moreover, biomass selection for the development of biofuels is also closely correlated with greenhouse gas emissions, environmental sustainability, and economic sustainability [15].

Algal biomass is recyclable as well. After reducing primary fuels in the form of hydrogen, methane, biodiesel, and bioethanol, the use of micro-algal biomass could be a promising path. This algal biomass, referred to as spent microalgal biomass (SMAB), carries up to $70 \%$ of its commencing energy level and retains proteins, carbohydrates and lipids, and nutrients. This may be an added bonus to algae selection as the future source of biomass.

The key components of all algae are lipids, carbohydrates, proteins, and nucleic acids. As an indication of its composition, the chemical investigation of algae samples is given in Table 3. 
Table 3. Chemical investigation of algae samples (dry matter basis, \%)[16].

\begin{tabular}{l|l|l|l|l} 
Sample organisms & Carbohydrates & Proteins & Lipids & Nucleic acid \\
\hline Scenedesmus obliquus & $10-17$ & $50-56$ & $12-14$ & $3-6$ \\
\hline Spirogyra sp. & $33-64$ & $6-20$ & $11-21$ & - \\
\hline Scenedesmus quadricauda & - & $44-50$ & $1.8-2.1$ & - \\
\hline Scenedesmus dimorphus & $21-52$ & $8-18$ & $16-40$ & - \\
\hline Chlamydomonas reinhardtii & $15-19$ & $50-46$ & $18-24$ & - \\
\hline Chlorella vulgaris & $12-17$ & $51-58$ & $14-22$ & $4-5$ \\
\hline Chlorella pyrenoidosa & $24-28$ & $55-59$ & $1-3$ & - \\
\hline Dunaliella bioculata & $3-5$ & $47-51$ & $6-10$ & - \\
\hline Dunaliella salina & $30-34$ & $55-59$ & $5-7$ & - \\
\hline Euglena gracilis & $14-18$ & $39-61$ & $14-20$ & - \\
\hline Spirulina platensis & $8-14$ & $46-63$ & $4-9$ & $2-5$ \\
\hline Prymnesium parvum & $25-33$ & $28-45$ & $22-38$ & $1-2$ \\
\hline Tetraselmis maculata & $14-16$ & $50-54$ & $2-4$ & - \\
\hline Porphyridium cruentum & $40-57$ & $28-39$ & $9-14$ & - \\
\hline Spirulina maxima & $13-16$ & $60-71$ & $6-7$ & $3-4.5$ \\
\hline Synechococcus sp. & $14-16$ & $62-64$ & $10-12$ & $4-6$ \\
\hline Anabaena cylindrica & $25-30$ & $43-56$ & $4-7$ & -
\end{tabular}

It is clear from the data shown in the table above that microalgae are primarily constructed with proteins, lipids, and water-soluble carbohydrates.

$$
\text { Light }+\mathrm{CO}_{2}+\mathrm{H}_{2} \mathrm{O}+\text { Nutrients } \stackrel{\text { Algal cell }}{\longrightarrow} \text { Lipids }+ \text { Carbohydrates }+ \text { Proteins }
$$

The above equation shows that microalgae are well-suited biomasses for transforming into biofuels such as biodiesel from lipids, ethanol and/or hydrogen from carbohydrates, and fertilizer from proteins [16-17].

In the composition and metabolism of micro-algal cells, proteins play a significant role. Similar to various catalytic enzymes involved in photosynthesis, they are a crucial part of the membrane and light-harvesting complex. The protein content of various micro-algal species can interact with traditional protein sources quantitatively and qualitatively. Numerous organisms of microalgae are known to have elevated protein concentrations in terms of quantity; this can differ from 42 percent to over 70 percent in some cyanobacteria and up to 58 percent on the basis of dry weight for Chlorella vulgaris [18]. In terms of quality, microalgae consist of entire essential amino acids that mammals cannot synthesize. In addition, the amino acid profiles like lactoglobulin, egg albumin, and soy, are well-proportioned and quite equivalent to greater quality protein sources [19].

Carbohydrates have both structural and metabolic roles, namely mono-, oligo-, and polysaccharides. Carbohydrates can be observed bound to proteins or lipids (e.g., glycoproteins and glycolipids), and the main structural characteristics of the cell wall are complex polysaccharides [20]. In addition, glucose and starch-like energy storage products, which are the basic photosynthesis yields consists of carbon, are made from microalgae. According to the microalgae community, polysaccharides are developed in several pathways. While some species synthesize semi-amylopectin, Cyanophytes are reported to accumulate glycogen [21]. Chlorophyta synthesizes starch in the form of two glucose polymers, amylopectin, and amylose, whereas Rhodophyta generates a carbohydrate polymer known as Floridian starch [22].

The microalgae lipid fraction consists primarily of neutral lipids like acylglycerols, free fatty acids, and carotenoids, and polar lipids like different phospholipids and galactolipids. 
Basically, in the exponential stage of development, most of the microalgae are rich in polar lipids and accumulate triacylglycerols under stress conditions, ideally in the stationary stage when nutrients are minimal. Microalgae's fatty acid profile is ideally recognized by a combination of saturated and unsaturated fatty acids $\mathrm{C} 16$ and $\mathrm{C} 18$, along with extended carbon chain lengths like several omega fatty acids. In neutral lipid bodies, saturated fats are usually processed, while unsaturated fatty acids are often linked with polar lipids in the different membranes that preserve membrane fluidity under different growing circumstances. The lipid content is quite well documented in many microalgae species and can account for anywhere from $20 \%$ to $50 \%$ of dry biomass (w/w). Still, other values fluctuating from $1 \%$ to $70 \%$ have also been registered. The development of lipids tends to depend on the microalgae organisms, and the conditions of cultivation largely control the generation of various kinds of lipids, i.e., the stage of growth, availability of nutrients, salinity, temperature, light strength, and $\mathrm{pH}$ [18].

Vitamins (A, B1, B2, B6, and C) and minerals like iron, potassium, calcium, iodine, niacin, and magnesium can also be provided by micro-algae. Because of all major nutrients in microalgae, they are among the basic food sources in Asian nations, including Korea, Japan, and China. Owing to their nutritional value, they are also used in other parts of the world [16].

\subsection{Growth conditions of algae.}

\subsubsection{Light.}

Algae can be quickly cultivated and grown anywhere with fewer energy requirements and very few nutrients. For micro-algal cultures, the optimal growth conditions are strainspecific, and biomass productivity relies on several factors. Abiotic variables including temperature, minerals, carbon dioxide, $\mathrm{pH}$, quality of water, light cycle, and intensity are included. The two most significant factors that influence the productivity of algae biomass are light and temperature. Via photosynthesis, the energy for growing algae is generated by light. To achieve higher biomass productivity, adequate light energy must be used effectively [23].

Light is the most important factor controlling micro-algae growth and storage materials. A decrease in dry weight is caused by low light intensity, whereas increased intensity brings biochemical injury to photosynthetic machinery or photoinhibition. Light is restricted without photo-inhibition under most incubation conditions in specific with a comparatively greater cell concentration. The higher the light intensity applied (from 35 to $400 \mathrm{mEm}^{-2} \mathrm{~s}^{-1}$ ), the higher the fatty acid and arachidonic acid content in the cells of the microalgae Parietochloris incisa. Similarly, micro-algae B. Braunii had the uppermost lipid yield of $0.45 \mathrm{~g} \mathrm{~L}^{-1}$ as the measured intensity raised from 0.3 to $538 \mathrm{mEm}^{-2} \mathrm{~s}^{-1}$. The results also revealed that algal growth was constrained by comparatively high light intensity but supported a rise in lipid content and yield. In order to avoid photo-oxidative injury, the handling of too many photo-assimilates, which can then be retained in lipid form, is likely to be a means of transforming excess light into chemical energy. The impact of the wavelength on the growth of B. Braunii has shown that red and blue lights are more efficient than a green light for growth, photosynthetic $\mathrm{CO}_{2}$ fixation, and hydrocarbon production, and that red light is the most efficient light source [24].2.3.2. Temperature.

The temperature, which directly affects the biochemical mechanisms in the algal cells, and photosynthesis, is also an additional significant element in microalgae growth. Each organism has its individual optimum temperature for growth. Raising the temperature to the optimum range improves the growth rate of the algae exponentially, but a rise or decline in 
temperature above the optimal level slows down or even inhibits the growth and activity of the algae [23]. While thermophilic algae-like Anacystis nidulans and Chaetoceros can withstand temperatures of up to $40^{\circ} \mathrm{C}$ and algae growing in hot springs near $80^{\circ} \mathrm{C}$ [26], the optimum temperature range is $20-30^{\circ} \mathrm{C}$ for most algal species [27]. Optimum growth temperature and the growth rate at the optimum temperature for some chlorophytes and blue-green algae are shown in this Table 4.

Table 4. Optimum temperature and growth at optimum temperature for some algal species [28].

\begin{tabular}{|c|c|c|c|}
\hline & Range tested $\left({ }^{\circ} \mathrm{C}\right)$ & Optimum $\left({ }^{\circ} \mathrm{C}\right)$ & $\begin{array}{c}\text { Growth rate at optimum } \\
\qquad\left(d^{-1}\right)\end{array}$ \\
\hline \multicolumn{4}{|l|}{ Chlorophytes } \\
\hline Ankistrodesmus falcatus & $5-35$ & 35 & 1.30 \\
\hline Chlorella sp. & $25-45$ & 35 & 1.63 \\
\hline Chlorella pyrenoidosa & $10-43$ & 40 & 2.56 \\
\hline Chlorella saccharophila & $5-30$ & 21 & 1.14 \\
\hline Chlorella sorokiniana & $10-30$ & 30 & 2 \\
\hline Chlorella vulgaris & $25-41$ & 35 & 5.28 \\
\hline Chlorogonium sp. & $25-40$ & 35 & 4.8 \\
\hline Closterium acutum & $10-30$ & 30 & 1.14 \\
\hline Coelastrum microporum & $15-35$ & 35 & 1.64 \\
\hline Cosmarium subprotumidum & $15-35$ & 35 & 1.00 \\
\hline Glaphyrella trebouxioides & $5-30$ & 18 & 0.79 \\
\hline Mychonastes homosphaera & $14-28$ & 20 & 1.19 \\
\hline Scenedesmus abundans & $10-35$ & 35 & 1.95 \\
\hline Scenedesmus acutus & $9.5-29$ & 24 & 1.84 \\
\hline Scenedesmus almeriensis & $10-45$ & 35 & 1.68 \\
\hline Scenedesmus dimorphus & $10-35$ & 35 & 1.5 \\
\hline Scenedesmus ecornis & $10-35$ & 30 & 2.1 \\
\hline Scenedesmus incrassulatus & $15-36$ & 30 & 1.13 \\
\hline Scenedesmus obliquus & $20-36$ & 32 & 1.22 \\
\hline Scenedesmus quadricauda & $3-25.5$ & 25.5 & 1.07 \\
\hline Selenastrum capricornutum & $15-39$ & 21 & 1.08 \\
\hline Staurastrum chaetoceras & $10-30$ & 30 & 0.86 \\
\hline Staurastrum cingulum & $2-35$ & 30 & 0.95 \\
\hline Staurastrum pingue & $10-30$ & 30 & 0.78 \\
\hline Staurastrum planctonicum & $10-30$ & 30 & 0.84 \\
\hline \multicolumn{4}{|l|}{ Blue-green algae } \\
\hline Anabaena aphanizomenoides & $10-35$ & 35 & $1.46^{*}$ \\
\hline Anabaena spiroides & $16-40$ & 24 & 0.77 \\
\hline Anabaena ukrainica & $5-32$ & 26 & 0.78 \\
\hline Anabaena variabilis & $25-45$ & 35 & 1.2 \\
\hline Anacystis nidulans & $25-45$ & 41 & 3.55 \\
\hline Cylindrospermopsis raciborskii & $12-32$ & 32 & 0.71 \\
\hline Merismopedia tenuissima & $15-30$ & 30 & 0.69 \\
\hline Microcoleus vaginatus & $15-39$ & 21 & 0.22 \\
\hline Microcystis sp. & $4-37$ & 25 & 0.35 \\
\hline Microcystis aeruginosa & $15-30$ & 30 & 1.09 \\
\hline Microcystis aeruginosa & $20-35$ & 32 & 1.6 \\
\hline Microcystis ichthyoblabe & $10-35$ & 35 & 1.32 \\
\hline Microcystis wesenbergii & $10-45$ & 35 & 1.5 \\
\hline Oscillatoria agardhii & $5-35$ & 30 & 1.12 \\
\hline Oscillatoria redekei & $5-35$ & 25 & 1.32 \\
\hline Phormidium bohneri & $5-35$ & 35 & 1.59 \\
\hline Synechococcus sp. & $14-28$ & 28 & 1.19 \\
\hline Synechocystis sp. & $20-41$ & 30 & 1.7 \\
\hline Synechocystis minima & $10-35$ & 32 & 1.32 \\
\hline Tychonema bourrellyi & $2-35$ & 17 & 1.07 \\
\hline
\end{tabular}


As growing microalgae can result in high biomass losses at non-optimal temperatures, the temperature is significant for large-scale cultivation. Reduced temperatures trouble photosynthesis by reducing the operation of carbon assimilation, while extreme temperatures decrease photosynthesis by disabling photosynthetic proteins and breaking up the cell's energy equilibrium. Higher temperatures also decrease the respiration and size of the cells. The dropin photosynthesis leads to a very low rate of growth [29].

A decrease in the action of ribulose-1, 5-bisphosphate (Rubisco), an enzyme with double tasks, is responsible for the main impact of temperature on photosynthesis. The relative concentrations of $\mathrm{O}_{2}$ and $\mathrm{CO}_{2}$ existing in chloroplasts can function as an oxygenase or carboxylase. The Rubisco enzyme's $\mathrm{CO}_{2}$ fixation activity rises to a certain amount with increasing temperatures and then decreases. As a result, the temperature is a critical element for the growth rate of algal and biomass generation due to its effect on the fondness of ribulose to $\mathrm{CO}_{2}$. As a stress therapy, the temperature can also be used to accelerate the production of usable metabolites. It is found that when grown at $25^{\circ} \mathrm{C}$, a Chlorella vulgaris culture developed more carbohydrates and lipids than at $30^{\circ} \mathrm{C}$ [5].

For several microalgae species, scientists have found that temperatures between 27 and $31^{\circ} \mathrm{C}$ were ideal, so light and temperature have a major impact on algae metabolism, enzyme activities, and cell composition [27].

\subsubsection{Other environmental conditions.}

Diurnal cycles and seasonal fluctuations can also modify the accessibility of sunlight, hence affecting the growth of microalgae [10]. With the ample availability of solar radiation throughout the year and saline water (either from the sea or as groundwater) in tropical or subtropical regions, they could generally be considered the fittest places for the mass cultivation of algae. However, the responses of the algal community for the light, temperature and other conditions depend on their inner characteristics, and they vary among different algal strains.

Cultivation of algae often relies on $\mathrm{pH}$ levels, and optimum $\mathrm{pH}$ affects the supply of biomass, metabolism, and cell biochemical composition. Another significant factor impacting the growth of microalgae is $\mathrm{pH}$. Species of microalgae have varying $\mathrm{pH}$ requirements [30]. Most of them thrive well in the $\mathrm{pH}$ range from 6 to 8.76. Most algae species are $\mathrm{pH}$ sensitive, and a small number of them can have a $\mathrm{pH}$ range as wide as that handled by $C$. vulgaris. $C$. vulgaris may develop in a wide range of $\mathrm{pH}$, but the highest growth rate and biomass yields are noticed at $\mathrm{pH} 9-10$. High $\mathrm{pH}$ will boost salinity, which is very hazardous to the cells of algae [31].

Various species of microalgae may differ widely in their nutrient needs, but the primary requisites for all species are the same. The microalgae backbone $(\mathrm{CH} 1.7 \mathrm{O} 0.4 \mathrm{~N} 0.15$ $\mathrm{P}$ 0.0094) is constructed by nitrogen, phosphorus, and carbon and is categorized as macronutrients necessary for algae growth. In addition, a few other organisms of marine microalgae also need silicon as a macronutrient [32].

$\mathrm{O}_{2}$ and $\mathrm{H}_{2}$ are absorbed from water by microalgae. For various species of microalgae, the amounts of macronutrients, including nitrogen and phosphorus, may differ. Chlorella growth has been reported to have decreased when nitrogen and phosphorus concentrations fell from 31.5 and $10.5 \mathrm{mg} / \mathrm{l}$, respectively. The amount of nitrogen accessible in the culture correlates with the cell growth directly. Limiting nitrogen in microalgae culture while increasing carbohydrate and lipid production will decrease biomass productivity and growth 
[5]. The optimum concentration of $0.5 \mathrm{~g} / \mathrm{l}$ nitrogen for, Chlorella vulgaris at which $3.43 \mathrm{~g} / \mathrm{l}$ biomass is produced has been shown [31].

$\mathrm{Mo}, \mathrm{Co}, \mathrm{K}, \mathrm{Mg}, \mathrm{Mn}, \mathrm{Fe}, \mathrm{B}$, and $\mathrm{Zn}$ micronutrients are required only in very little quantities but have a crucial role in microalgae growth, as they control numerous enzymatic functions in algal cells [33].

The basic inorganic nutrients that are significant for microalgae growth are $\mathrm{P}, \mathrm{N}$, and C. Nutrient deficiency significantly impacts the growth rate of microalgae and results in low biomass. The availability of nutrients greatly influences the synthesis and accumulation of carbohydrates and lipids in microalgae [34]. As stated in earlier research, the impact of varying environmental conditions on algal growth has been given in Table 5.

Table 5. Impacts of varying environmental conditions observed on the growth of algae $[6,35,36]$.

\begin{tabular}{|c|c|c|}
\hline Strains of algal species & Conditions evaluated & Recognizable impacts \\
\hline Pleurochrysis carterae & $\mathrm{pH}$ & $\begin{array}{l}\text { Supreme productivities utilizing plate photo } \\
\text { bioreactor at } \mathrm{pH} \text { 7.7-8.0. } \\
\text { Supreme productivity in outdoor raceway pond at } \\
\text { pH 9.1-9.6. }\end{array}$ \\
\hline Not specified & $\begin{array}{l}\text { Relationship among } \\
\text { supplied } \mathrm{CO}_{2} \text { and } \mathrm{pH}\end{array}$ & $\begin{array}{l}\text { The hydration of } \mathrm{CO}_{2} \text { and consequent formation } \\
\text { of bicarbonate ions is quicker at } \mathrm{pH} \text { values below } \\
8 \text {. } \\
\text { Direct reaction of } \mathrm{CO}_{2} \text { with the hydroxyl ion to } \\
\text { form bicarbonate occurred best at above } \mathrm{pH} 10 \text {. }\end{array}$ \\
\hline Not specified & $\begin{array}{l}\text { Relationship among given } \\
\mathrm{CO}_{2} \text { and } \mathrm{pH}\end{array}$ & $\begin{array}{l}\mathrm{CO}_{2} \text { given at near-neutral } \mathrm{pH} \text { led to the massive } \\
\mathrm{CO}_{2} \text { release into the atmosphere }\end{array}$ \\
\hline Nannochloropsis oculata & Concentration of $\mathrm{CO}_{2}$ & $\begin{array}{l}\text { Biomass production and lipid accumulation } \\
\text { increase followed by an increase in } \mathrm{CO}_{2} \\
\text { concentration }\end{array}$ \\
\hline $\begin{array}{l}\text { Scenedesmus obliquus } \\
\text { Chlorella kessleri } \\
\text { Spirulina sp } \\
\text { Chlorella vulgaris. }\end{array}$ & Concentration of $\mathrm{CO}_{2}$ & $\begin{array}{l}\text { Scenedesmus obliquus and Chlorella kessleri } \\
\text { were stated to acquire the capability of } \mathrm{CO}_{2} \text { bio- } \\
\text { fixation. }\end{array}$ \\
\hline Haematococcus pluvialis & Aeration and light intensity & $\begin{array}{l}\text { Higher growth stated in the aerated column as } \\
\text { aeration. } \\
\text { Sedimentation was blocked, and good contiguity } \\
\text { among cells and nutrients. } \\
\text { The rise in light intensity enhanced greater cell } \\
\text { density and growth rate up to a certain level } \\
\text { beyond which it inhibited growth. }\end{array}$ \\
\hline $\begin{array}{l}\text { Botryococcus } \\
\text { Nitzschia } \text { sp. } \\
\text { Isochrysis } \\
\text { Dunaliella } \text { sp. }\end{array}$ & Nitrogen and salt stress & $\begin{array}{l}\text { Lesser levels of lipids were seen in Dunaliella sp. } \\
(23 \%) \text {, Nitzschia sp. (12\%), and Isochrysis ( } 7 \%) \text {. } \\
\text { Under non-stressed conditions, Botryococcus } \\
\text { facilitated elevated lipid concentration. }\end{array}$ \\
\hline $\begin{array}{l}\text { Chlorella emersonii } \\
\text { Chlorella vulgaris } \\
\text { Chlorella minutissima }\end{array}$ & Nitrogen stress & $\begin{array}{l}63 \%, 56 \% \text {, and } 40 \% \text { increase in lipid content of } \\
\text { C.emersonii, C. minutissima, and C. vulgaris, } \\
\text { respectively }\end{array}$ \\
\hline Chlorella vulgaris & Concentration of iron & $\begin{array}{l}\text { Greater iron concentrations improved lipid } \\
\text { accumulation }\end{array}$ \\
\hline $\begin{array}{l}\text { Botryococcus } \\
\text { Isochrysis } \\
\text { Dunaliella bardawil } \\
\text { Dunaliella salina }\end{array}$ & Nitrogen stress & $\begin{array}{l}\text { Botryococcus lipids raised (10\%) with } \mathrm{N}_{2} \\
\text { increase. } \\
\text { Dunaliella bardawil and Dunaliella salina lipids } \\
\text { reduced (10\%) with } \mathrm{N}_{2} \text { rise. } \\
\text { Isochrysis lipids and carbohydrates rose up with } \\
\text { the drop in } \mathrm{N}_{2} \text {. } \\
\text { Chlorophyll and Protein content reduced, whereas } \\
\text { lipids and carbohydrates showed a species- } \\
\text { specific pattern. }\end{array}$ \\
\hline
\end{tabular}




\begin{tabular}{l|l|l}
\multicolumn{1}{c|}{ Strains of algal species } & Conditions evaluated & \multicolumn{1}{c}{ Recognizable impacts } \\
\hline Spirulina maxima & $\begin{array}{l}\text { Temperature and nitrogen } \\
\text { stress }\end{array}$ & $\begin{array}{l}\text { Spirulina lipids content rose up 3 times with the } \\
\text { reduction of nitrogen content and temperature } \\
\text { decline, being the nitrogen concentration decline } \\
\text { more efficient. }\end{array}$
\end{tabular}

\subsection{Harvesting of micro-algae.}

The harvesting of algae is defined as the isolation or detachment from the growth medium of the algae. The harvesting process is heavily dependent on the physiognomy of the selected micro-algae, the size and density of the micro-algae cell, and the characteristics of the ultimate outcome. Microalgae harvesting is one of the key components of the development of microalgae. Several studies have shown that it accounts for 20-30 percent of the overall cost of production because of its high energy demand [1]. Numerous mechanical, chemical, biological and electrical harvesting technologies have been used to collect biomass, including filtration, centrifugation, flocculation, and flotation [37]. In certain cases, a combination of two or more methods is utilized to improve the productivity of harvesting further. A list of harvesting techniques and their target microalgae organisms, benefits, and drawbacks are presented in Table 6.

Table 6. Different harvesting techniques and their target microalgae organisms with their benefits and

\begin{tabular}{|c|c|c|c|c|}
\hline $\begin{array}{l}\text { Harvesting } \\
\text { technique }\end{array}$ & $\begin{array}{l}\text { Microalgae } \\
\text { organisms }\end{array}$ & Benefits & Drawbacks & References \\
\hline $\begin{array}{l}\text { Axial vibration } \\
\text { membrane filtration }\end{array}$ & Chlorella pyrenoidosa & $\begin{array}{l}\text { Low membrane } \\
\text { fouling }\end{array}$ & $\begin{array}{l}\text { need power- } \\
\text { enthralling pumping } \\
\text { units }\end{array}$ & {$[38]$} \\
\hline Cross flow filtration & Chlorella sp. & $\begin{array}{l}\text { Increased energy } \\
\text { efficiency }\end{array}$ & $\begin{array}{l}\text { Susceptible to } \\
\text { membrane fouling and } \\
\text { shearing of fragile } \\
\text { materials }\end{array}$ & [39] \\
\hline Ultrafiltration & Dunaliella salina & $\begin{array}{l}\text { Reduced cell } \\
\text { shearing, low } \\
\text { energy, and } \\
\text { chemical } \\
\text { consumption }\end{array}$ & $\begin{array}{l}\text { Greater investment } \\
\text { cost }\end{array}$ & {$[40]$} \\
\hline $\begin{array}{l}\text { Polyacrylonitrile- } \\
\text { based membrane } \\
\text { filtration }\end{array}$ & $\begin{array}{l}\text { Scenedesmus and } \\
\text { Phaeodactylum }\end{array}$ & $\begin{array}{l}\text { Low membrane } \\
\text { fouling }\end{array}$ & $\begin{array}{l}\text { Need power- } \\
\text { enthralling pumping } \\
\text { units }\end{array}$ & [41] \\
\hline $\begin{array}{l}\text { Tilted membrane } \\
\text { panel filtration }\end{array}$ & Wild microalgae strain & $\begin{array}{l}\text { Low membrane } \\
\text { cost and energy } \\
\text { consumption }\end{array}$ & Membrane fouling & {$[42]$} \\
\hline $\begin{array}{l}\text { Microbial bio } \\
\text { flocculation }\end{array}$ & $\begin{array}{l}\text { Desmodesmus } \\
\text { brasiliensis }\end{array}$ & $\begin{array}{l}\text { Cost-effective and } \\
\text { eco-friendly }\end{array}$ & $\begin{array}{l}\text { Spoilage by } \\
\text { microalgae products }\end{array}$ & [43] \\
\hline Electro-flocculation & D. salina & $\begin{array}{l}\text { Cost-effective and } \\
\text { no use of } \\
\text { chemicals }\end{array}$ & Energy-intensive & {$[1]$} \\
\hline $\begin{array}{l}\text { Plant bio- } \\
\text { flocculation } \\
(\text { Moringa oleifera })\end{array}$ & Chlorella sp. & $\begin{array}{l}\text { Cost-effective and } \\
\text { limited toxicity }\end{array}$ & $\begin{array}{l}\text { Spoilage by } \\
\text { microalgae products }\end{array}$ & [44] \\
\hline Buoy-bead flotation & Chlorella vulgaris & $\begin{array}{l}\text { No use of } \\
\text { chemicals and } \\
\text { greater reusability }\end{array}$ & Expensive method & {$[45]$} \\
\hline $\begin{array}{l}\text { Magnesium } \\
\text { Coagulation } \\
\text { dissolved air } \\
\text { flotation }\end{array}$ & Chlorella zofingiensis & $\begin{array}{l}\text { Does not use } \\
\text { external coagulant } \\
\text { and increased } \\
\text { recyclability of }\end{array}$ & $\begin{array}{l}\text { Use of toxic } \\
\text { chemicals }\end{array}$ & [46] \\
\hline s://biointerfacere & & & & \\
\hline
\end{tabular}




\begin{tabular}{|c|c|c|c|c|}
\hline $\begin{array}{l}\text { Harvesting } \\
\text { technique }\end{array}$ & $\begin{array}{l}\text { Microalgae } \\
\text { organisms }\end{array}$ & Benefits & Drawbacks & References \\
\hline & & $\begin{array}{l}\text { coagulant and } \\
\text { biomass }\end{array}$ & & \\
\hline $\begin{array}{l}\text { Chemical } \\
\text { flocculation }\end{array}$ & Chlorella sp. & $\begin{array}{l}\text { Cost-effective and } \\
\text { simple to execute }\end{array}$ & $\begin{array}{l}\text { Use of toxic } \\
\text { chemicals }\end{array}$ & [47] \\
\hline Foam flotation & $\begin{array}{l}\text { C. vulgaris, Isochrysis } \\
\text { galbana, and } \\
\text { Tetraselmis suecica }\end{array}$ & $\begin{array}{l}\text { inexpensive and } \\
\text { low power } \\
\text { demand, Easy to } \\
\text { execute }\end{array}$ & $\begin{array}{l}\text { Investment and } \\
\text { maintenance costs are } \\
\text { high }\end{array}$ & [48] \\
\hline Electrolytic flotation & C. vulgaris & $\begin{array}{l}\text { No use of } \\
\text { chemicals, reduced } \\
\text { energy demand, } \\
\text { and can be utilized } \\
\text { in a continuous } \\
\text { system }\end{array}$ & $\begin{array}{l}\text { Investment and } \\
\text { maintenance costs are } \\
\text { high }\end{array}$ & [49] \\
\hline Ozone flotation & Scenedesmus sp. & $\begin{array}{l}\text { High recovery of } \\
\text { microalgae bio- } \\
\text { compounds }\end{array}$ & $\begin{array}{l}\text { Need specified ozone } \\
\text { generation tools onsite }\end{array}$ & [50] \\
\hline
\end{tabular}

\subsubsection{Filtration.}

The filtration method utilizes a semi-permeable membrane that can hold microalgae on the membrane, permitting the liquid media to move through, leaving behind the collection of micro-algal biomass [51]. This method can extract high cell concentrations from the medium, and the differing pore dimension of the filter membrane helps the processes satisfy the requirement for various microalgae and manipulate the more fragile organisms that are susceptible to compressive injury. However, this technique is vulnerable to fouling and obstruction and thus involves regular adjustments to the membrane or fresh filter that could drastically add to its operating expense. In consideration of this obstruction, the filter membrane was constructed incorporating inexpensive and easily available materials. As a result, a stretch cotton filter membrane capable of achieving 66-93 percent harvesting efficiency has been successfully generated by Bejor et al. [1].

\subsubsection{Centrifugation.}

The centrifugation process uses centrifugal force to isolate microalgae cells from culture media based on the portion's density and particle size [52]. This approach has a greater efficiency for cell harvesting, but the protocol is time demanding and energy demanding. In addition, the increased gravitational force used in centrifugation could damage the cells, changing it unfavorable for some applications as the sensitive nutrients could disappear. The industry has used various kinds of centrifugal systems, including disk stack centrifuges, perforated basket centrifuges, imperforated basket centrifuges, decanters, and hydro-cyclones [37].

\subsubsection{Flocculation.}

Flocculation is a mechanism in which free-floating single cellular microalgae cells accumulate together by applying a flocculating mediator to eliminate the surface charge of cells to make a bigger particle which is known as floc. It is possible to divide flocculating agents into two major groups, named chemical flocculants and bio-flocculants. Inexpensive and frequently usable chemical flocculants, including iron and aluminum salts, have been 
commonly utilized in the industry [53]. The research conducted by Chatsungnoen and Chistt [54] showed that metal salts like aluminum sulfate and iron chloride can remove approximately 95\% of the microalgae biomass in standard conditions. However, because of their high toxicity, the chemicals are not eco-friendly and should be eliminated by further treatment procedures that add to the cost of production [55].

In contrast, bio-flocculants are safer and more environmentally friendly than their chemical counterparts. They are also inexpensive to use, and prior to additional downstream processing of microalgae and culture media recycling, there is usually no pre-treatment required [56]. Biopolymers, including acrylic acid and chitosan, which occur naturally or are manufactured artificially, are most bio-flocculants used [57]. Compared to chemical flocculants like aluminum sulfate that require higher concentrations to obtain the equivalent outcomes, chitosan at a lower dose is stated to achieve $90 \%$ cell recovery [58].

\subsubsection{Flotation.}

To facilitate the floating of cells on the surface of the culture media for easy harvesting, flotation utilizes tiny bubbles that bind to microalgae cells [59]. Comparatively greater harvesting performance, simple maintaining protocol, and greater processing throughput at minimal expenses are the benefits associated with the flotation method [60]. There are 3 major types of flotation models that use different mechanisms to produce air bubbles. The dissolved air flotation system creates air bubbles by overloading the culture with pressurized gas and then discharging the culture at ambient pressure. This technique has been generally used to treat wastewater but is hampered by high costs due to the use of resources and the use of chemicals. In contrast, dispersed air flotation uses a sparger to produce air bubbles which consecutively have lesser energy needs than the dissolved air flotation. Electro-flotation, which applies electrolysis to produce microbubbles from its electrode to capture free-floating microalgae, is the third technique. In addition to harvesting, this technique also enables concurrent cell disruption activity while alternating current is utilized. However, due to fouling, the corresponding device is very energy-demanding, and regular electrode replacement is needed, increasing the cost of output [37].

\subsubsection{Magnetic separation.}

Traditional approaches to harvesting microalgae, such as floatation, filtration, electrolysis, and centrifugation, face the constraints of increased expenses, energy intensity, and complex processes. Magnetic separation was also implemented as an effective tool for micro-algal harvesting alongside these conventional methods. High performance and low running costs, along with quick and rapid processing, are the key benefits of magnetic separation processes [61].

Molecular aggregates or atomic with at least one dimension between 1 and $100 \mathrm{~nm}$ were known as nanoparticles (NPs), with dramatically swapped physical-chemical features compared to the bulk content [62]. Magnetic nanoparticles (MNPs) are mainly nanoparticles used for microalgae harvesting because magnetic separation allows quick, automated, and scalable processing with greater harvesting efficiency and lesser contamination [63].

In addition, magnetic nanoparticles have small sizes, special physicochemical characteristics, and lesser production costs [64]. The primary categories of magnetic particles used for algal harvesting are bare (naked), coated, and surface-modified [65]. 


\section{a. Naked (bare) magnetic particles}

Naked iron oxide nanoparticles, which are generally known to be inexpensive and simple to operate, have been employed to research the detachment of microalgae. Effective detachment is possible under a varying ecological parameter and depends basically on the mass ratio of nanoparticles to microalgae when the mass ratio is suitably selected, while the impact of $\mathrm{pH}$ and ionic strength is not very important. This magnetic nanoparticle application is an example of the projections provided by nano-biotechnology for biomass exploitation. For Scenedesmus ovalternus and Chlorella vulgaris, the increased affinity of the cell walls for the inorganic surface permits harvesting efficiencies larger than 95 percent [66-67].

The $\mathrm{Fe}_{3} \mathrm{O}_{4}$ particles generated by chemical co-precipitation were successful in harvesting Botryococcus braunii and Chlorella ellipsoidea freshwater algal species. In another study, $\mathrm{Fe}_{3} \mathrm{O}_{4}$ nanoparticles were utilized for the effective processing of Nannochloropsis maritima marine microalgae. At the particle dose of $120 \mathrm{mg} / \mathrm{L}$ within 4 minutes, the recovery efficiency of cells from the culture medium was more than 95 percent. It has been reported that naked magnetite has ion exchange features, and the detachment is mainly based on the electrostatic interactions among the magnetite and the algal cells. Furthermore, Fe ions released from the surface of naked iron oxide magnetic micro-particles can act as flocculating agents and support the procedure of harvesting. However, in the harvested algal cells, the released ions can raise the metal content, and this can affect the downstream processing of the biomass of algae. For example, Fe can poison the desulfurization catalysts and reduce the yield of gasoline. Hence, the possible effect on the downstream process should be considered in the choice of magnetic adsorbent [68].

When the $\mathrm{pH}$ value decreases, the efficiency of harvesting increases dramatically. Therefore, the low $\mathrm{pH}$ value assigned to the protonation of the surface of the nanoparticles is beneficial for adsorption among the algae cells and the nanoparticles [69]. The addition of the stirring mechanism to help the binding of the iron oxide nanoparticles and the micro-algal cell surface before subjection to the extrinsic magnetic field is a very important phenomenon on improving the harvesting effectiveness of microalgae. It is expected that this step will improve the productivity of harvesting significantly [65].

\section{b. Coated and surface-modified nanoparticles.}

To minimize free interfacial energy, a microorganism prefers to bind to solid substrates in general. The overall extent of interactions, including non-covalent Lifshitz van der Waals forces, electrostatic forces, and acid-base interactions, must be known throughout algal binding to magnetic particles in an aqueous atmosphere. This triggers harvest suppression, so it is essential to change magnetic nanomaterials. Cationic polymers are mostly employed as coating chemicals because of their negative surface charges on most microalgae [70]. For rapid microalgae harvesting, several authors have studied various coatings of magnetic nanoparticles. Wang et al. [71] successfully applied a coating of positively branched dendrimer to enhance the yield of microalgae. They have found that the algae yield increases as the thickness of the dendrimer coating are increased. They have also developed a technique for synthesizing the required dendrimer and also assure that they can be regenerated and applied repeatedly. Table 7 depicts information on some of the earlier research carried out using Coated and surface-modified nanoparticles in harvesting and the research findings. 
Table 7. Findings of the earlier researches carried out with the use of Coated and surface-modified nanoparticles in harvesting.

Coated and surfacemodified nanoparticles

Nanoparticles + Polyarginine (PA)

\begin{tabular}{l|l|} 
& Fe3O4-PEI nanocomposites \\
\hline $\begin{array}{l}\text { Nanoparticles }+ \\
\text { Polyamidoamine }\end{array}$ & $\begin{array}{l}\text { Magnetic iron oxide coated } \\
\text { separately using dendrimer } \\
\text { (amino riched } \\
\text { polyamidoamine }=\text { PANAM), } \\
\text { and the amino acid was }\end{array}$
\end{tabular}

and the amino acid was

compared for effective

harvesting of oleaginous

Chlorella sp.

\begin{tabular}{l} 
Nanoparticles + \\
Polyaluminium chloride \\
(PACl) + \\
polyacrylamide (PAM) \\
\hline Nanoparticles + chitosan \\
\\
Nanoparticles + Poly \\
(diallyldimethylammoni \\
um chloride) (PDDA)
\end{tabular}

Dosing the composite
PACl/ $\mathrm{Fe}_{3} \mathrm{O}_{4}$ first, followed by
dosing $\mathrm{PAM}$.
dosing PAM.
Harvesting procedure of oleaginous microalgae

Chlorella sp. It was examined

by utilizing chitosan-Fe3O4

nanoparticle composites

Magnetic graphene oxide

(GO) nanocomposite coated

using cationic polymer

\begin{tabular}{|c|}
\hline Mode of synthesis \\
\hline $\begin{array}{l}\text { Highly positive long-chain } \\
\text { poly-arginine was used to } \\
\text { alter magnetic porous } \mathrm{Fe}_{3} \mathrm{O}_{4} \text {. } \\
\text { The alteration was attained by } \\
\text { first coupling amino silane on } \\
\text { p-Fe } \mathrm{O}_{4} \text { to obtain free amino } \\
\text { groups on the surface; then, } \\
\text { amidation was used to } \\
\text { connect the poly-arginine and } \\
\text { the free amino groups, with } \\
\text { the use of carbodiimide as a } \\
\text { dehydrator. }\end{array}$ \\
\hline
\end{tabular}

Polyethylenimine (PEI) is

recognized for its greater

density of positive charge and

was utilized to coat the

surface of magnetite

nanoparticles to get the

cationic charge on the

Fe3O4-PEI nanocomposites

\begin{tabular}{|l|l}
\multicolumn{1}{|c|}{ Findings } & \multicolumn{1}{c}{ References } \\
\hline $\begin{array}{l}\text { The optimal molecular } \\
\text { weight of Poly arginine and }\end{array}$ & {$[72]$}
\end{tabular}

maintaining a wide $\mathrm{pH}$

range could improve the

efficiency.

These nanomaterials could

keep up better recycling

stability and reach greater

harvesting efficiency after 5

regeneration cycles

Proper nano-composite
dosage, suitable $\mathrm{pH}$ range

and time duration could

help in improving the

efficiency.

Harvesting efficiency was

positively correlated with

temperature and negatively

correlated with $\mathrm{pH}$ here.

Highly positive branched

[71]

PANAM dendrimer

enhanced the adsorption.

It was positively correlated

with the coating thickness.

Efficiency improved when

pH was brought down to 4

from 8

\section{Dosing the composite}

$\mathrm{PACl} / \mathrm{Fe}_{3} \mathrm{O}_{4}$ first, followed

by dosing PAM could

increase the efficiency.

Alkaline $\mathrm{pH}$ could be

beneficial.

PDDA (diallyldimethyl

ammonium chloride) was

used for harvesting

oleaginous microalgae

Chlorella $\mathrm{sp}$.

because of the highly

[73] and [74]

[75]
Maintaining a proper $\mathrm{pH}$ range (2-12) could increase

the harvesting efficiency.

Maintaining proper $\mathrm{pH}$

[69]

positive charge and stable

property of graphene base

could increase the

efficiency.

Nanomaterials could keep up high recycling stability and attain greater

harvesting efficiency after 5

cycling times by utilizing a

raw/reactivated mixture

strategy,

[61] 


\begin{tabular}{l|l|l|l}
\hline $\begin{array}{l}\text { Coated and surface- } \\
\text { modified nanoparticles }\end{array}$ & \multicolumn{1}{|c|}{ Mode of synthesis } & \multicolumn{1}{|c}{ Findings } & References \\
\hline $\begin{array}{l}\text { Nanoparticles + Fumed } \\
\text { silica particles }\end{array}$ & $\begin{array}{l}\text { Flame-derived silica-coated } \\
\text { magnetic particles were used } \\
\text { in harvesting. }\end{array}$ & $\begin{array}{l}\text { Elevated pH and the } \\
\text { existence of di- and } \\
\text { trivalent ions improved } \\
\text { flocculation and increased } \\
\text { efficiency. }\end{array}$ & {$[61]$} \\
\hline $\begin{array}{l}\text { Nanoparticles + Plant } \\
\text { Polyphenol (PP) }\end{array}$ & $\begin{array}{l}\text { Magnetic harvesting of } \\
\text { Chlorella vulgaris using } \\
\text { magnetic particles coated } \\
\text { with plant polyphenol (PP). } \\
\text { Polyphenol was chemically } \\
\text { altered with the use of } \\
\text { Mannich reaction, } \\
\text { subsequently using } \\
\text { quaternization to boost its } \\
\text { fondness to microalgae cells } \\
\text { and raise the potential for } \\
\text { polymerization }\end{array}$ & $\begin{array}{l}\text { (96\%)covery) of the } \\
\text { cell aggregates was } \\
\text { achieved by ultrasounds } \\
\text { application }\end{array}$ & {$[76]$} \\
\end{tabular}

Magnetic separation was recorded almost forty years ago as a simple method for algae removal. During microalgae harvesting processes, it is able to attain more than 90 percent of cell recovery in not more than 5 minutes. Magnetic harvesting combines flocculation and magnetic separation in a single method, providing benefits like rapid, quick, energy-efficient, and lesser cost. Furthermore, the external magnetic field allows the concentration of magnetically transformed cells into a compact slurry and the removal in a lesser time higher quantity of bulk liquid. In magnetic algae harvesting, both naked and surface-modified magnetic nanoparticles have better efficiency, but their cost-efficiency in commercial application requires additional research to determine their practical feasibility [75].

\subsection{Processing of algae.}

Numerous methods have been used in the processing of micro-algae, and they vary in their efficiency and some frequently used methods are listed in Table 8 with their pros and cons.

Table 8. Advantages, drawbacks, and cost involvement of various methods of processing of micro-algae [77-

81].

\begin{tabular}{|c|c|c|c|}
\hline Method & Advantages & Drawbacks & Cost involvement \\
\hline Expeller Press & $\begin{array}{l}\text { No solvent is required. } \\
\text { Easy operation. }\end{array}$ & $\begin{array}{l}\text { Mechanical methods are } \\
\text { energy-intensive. }\end{array}$ & High cost \\
\hline Bead-beating /mill & $\begin{array}{l}\text { No solvent } \\
\text { required }\end{array}$ & $\begin{array}{l}\text { Mechanical methods are } \\
\text { energy-intensive. }\end{array}$ & Cost-effective \\
\hline $\begin{array}{l}\text { Pressurized solvent } \\
\text { extraction }\end{array}$ & $\begin{array}{l}\text { Solvent use is relatively } \\
\text { inexpensive }\end{array}$ & $\begin{array}{l}\text { Energy-intensive } \\
\text { (distillation is needed for } \\
\text { the extraction of lipid from } \\
\text { the solvents). } \\
\text { The solvent may be toxic }\end{array}$ & $\begin{array}{l}\text { High cost due to the } \\
\text { cumulative expenses } \\
\text { incurred by the use of } \\
\text { solvent and pressurized } \\
\text { nitrogen }\end{array}$ \\
\hline Soxhlet extraction & $\begin{array}{l}\text { Solvent use is relatively } \\
\text { inexpensive }\end{array}$ & $\begin{array}{l}\text { Time-consuming and not } \\
\text { suitable for large scale. }\end{array}$ & High cost \\
\hline Ultrasonic extraction & $\begin{array}{l}\text { Minimize the chemical } \\
\text { conversion time by up to } 90 \% \text {. } \\
\text { Eco friendly. } \\
\text { Can replace the solvents with } \\
\text { GRAS solvents }\end{array}$ & $\begin{array}{l}\text { The solvent is needed to } \\
\text { improve the recovery of } \\
\text { lipid. } \\
\text { The decline of power with } \\
\text { time. } \\
\text { No uniform distribution of } \\
\text { ultra-sound energy. }\end{array}$ & $\begin{array}{l}\text { Initial investment and } \\
\text { maintenance costs high }\end{array}$ \\
\hline
\end{tabular}




\begin{tabular}{|c|c|c|c|}
\hline Method & Advantages & Drawbacks & Cost involvement \\
\hline Osmotic shock & $\begin{array}{l}\text { No costly steps and } \\
\text { requirement of solvents like } \\
\text { other methods. }\end{array}$ & $\begin{array}{l}\text { Longer duration of } \\
\text { treatment time. }\end{array}$ & Low-cost method \\
\hline $\begin{array}{l}\text { Supercritical fluid } \\
\text { extraction }\end{array}$ & $\begin{array}{l}\text { Usage of less toxic solvents for } \\
\text { the extraction. } \\
\text { Suitable for thermo-labile } \\
\text { compounds. } \\
\text { Environmentally friendly. }\end{array}$ & $\begin{array}{l}\text { Greater power consumption } \\
\text { and complications in } \\
\text { scaling up. } \\
\text { High capital investment. } \\
\text { No polar substances are } \\
\text { extracted. }\end{array}$ & High cost \\
\hline $\begin{array}{l}\text { Microwave-assisted } \\
\text { extraction }\end{array}$ & $\begin{array}{l}\text { Reduced solvent usage. } \\
\text { Higher extraction rate and } \\
\text { yield. }\end{array}$ & High capital cost & $\begin{array}{l}\text { initial investment and } \\
\text { maintenance costs high }\end{array}$ \\
\hline Pyrolysis & $\begin{array}{l}\text { Cost-effective. } \\
\text { Ease of storage, transport, and } \\
\text { preparation of bio-fuels by } \\
\text { upgrading the bio-oil. }\end{array}$ & $\begin{array}{l}\text { Highly viscid, harsh, and no } \\
\text { thermal stability. } \\
\text { It shows low calorific } \\
\text { values resemblance to the } \\
\text { reactant oil as it has } \\
\text { predominant oxygenated } \\
\text { molecules. } \\
\text { Catalyst deactivation will } \\
\text { occur. }\end{array}$ & Low-cost method \\
\hline Direct Bio photolysis & $\begin{array}{l}\text { Direct production of hydrogen } \\
\text { from water and sunlight. }\end{array}$ & $\begin{array}{l}\text { It needs high intensity of } \\
\text { light, low photochemical } \\
\text { efficiency, and } \mathrm{O}_{2} \text { is } \\
\text { inhibitory. }\end{array}$ & Economically feasible. \\
\hline Indirect bio photolysis & $\begin{array}{l}\text { Blue-green algae can produce } \\
\text { hydrogen from water and able } \\
\text { to fix } \mathrm{N}_{2} \text { from the atmosphere. }\end{array}$ & $\begin{array}{l}\text { Removal of uptake } \\
\text { hydrogenates is needed }\end{array}$ & Economically feasible. \\
\hline $\begin{array}{l}\text { Enzyme-Assisted } \\
\text { Extraction }\end{array}$ & $\begin{array}{l}\text { It is an environmentally } \\
\text { friendly and nontoxic process. } \\
\text { High yield. } \\
\text { Comparatively low-cost } \\
\text { process due to the use of food- } \\
\text { grade enzymes. }\end{array}$ & $\begin{array}{l}\text { It is troubled by the lipid } \\
\text { class composition and type } \\
\text { of microalgae. } \\
\text { It needs operation at } \\
\text { reduced temperatures with } \\
\text { high specificity/selectivity } \\
\text { for better efficiency. } \\
\text { Cost intensive. }\end{array}$ & High cost \\
\hline $\begin{array}{l}\text { Pulsed Electric Field- } \\
\text { Assisted Extraction }\end{array}$ & $\begin{array}{l}\text { High efficiency. } \\
\text { Less energy requirement. }\end{array}$ & $\begin{array}{l}\text { Initial investment and } \\
\text { maintenance costs are high }\end{array}$ & $\begin{array}{l}\text { Initial investment and } \\
\text { maintenance costs are } \\
\text { greater, but can be } \\
\text { operated at comparatively } \\
\text { lower costs }\end{array}$ \\
\hline
\end{tabular}

2.5.1. Bead beating /milling.

A mechanical cell disruption method is bead beating (also ball milling), which vigorously grinds cell suspension together with solid beads. A tubular vessel made of metal or thick glass consists of cellular suspension along with small metal or glass balls constitutes a ball mill. The balls roll in the opposite route to the vessel's rotating route by spinning around their axis. Because of the different rolling and falling balls, the cell disturbance occurs as an outcome of the grinding motion at elevated speeds. Chlorella vulgaris cells, Scenedesmus obliquus cells, and Spirulina sp. have been interrupted with the usage of ball mill. The energy supply required to damage the cells relies largely on the cell wall thickness and concentration. When the concentration is higher and cell debris can be readily isolated, cell disruption is most effective [79]. 


\subsubsection{Expeller method.}

Pressing/Expeller press requires the submission to high-pressure of the micro-algal biomass, which destroys cell walls and releases oil. Friction causes it to heat up as the raw material is pressed; in certain cases, the temperatures can reach $120^{\circ} \mathrm{F}$ in this method. As different algae strains vary highly in their physical features, several press configurations (screw, expeller, piston, etc., are best fit for particular types of algae. Sometimes in conjunction with chemical solvents, mechanical pressing is used. Many commercial vegetable oil manufacturers use a mixture of mechanical pressing and chemical solvents in extracting oil. Although easy compared to solvent extraction, pressing can be very energy demanding and shows lesser extraction efficiency (between $70-75 \%$ of oils from microalgae) [79].

\subsubsection{Pulsed Electric Field-Assisted Extraction}

Pulsed electrical fields (PEFs) may be utilized to accelerate mass transfer procedures by damaging cell membranes. The application of field strength of $0.5-1.0 \mathrm{kV} / \mathrm{cm}$ and treatment times of $100-10,000 \mu \mathrm{s}$ or field strength of $1-10 \mathrm{kV} / \mathrm{cm}$ and shorter times $(5-100 \mu \mathrm{s})$ determines a mild PEF treatment. Reversible or irreversible pores are formed in the membranes, relying on the strength, amplitude, time span, number, and frequency of repetition of external electrical pulses. In extracting bioactive compounds from biological matrices, the formation of irreversible pores is of vital importance [82]. For the reduction of natural resources, electrical field intensity treatments of 0.7 to $3 \mathrm{kV} / \mathrm{cm}$, specific energy of $1-20 \mathrm{~kJ} / \mathrm{kg}$, a few hundred pulses, and a full-time span of less than $1 \mathrm{~s}$ are usually used $(15-20 \mathrm{kV} / \mathrm{cm}$ and specific energy of $40-1000 \mathrm{~kJ} / \mathrm{kg}$ ) [83].

\subsubsection{Ultrasound-assisted extraction (UAE).}

The ultrasound-assisted extraction utilizes ultrasonic waves at frequencies between 20 $\mathrm{kHz}$ and $100 \mathrm{kHz}$. These waves trigger bubbles and high- and low-pressure zones to be formed. As bubbles burst, cavitation occurs in the powerful ultrasonic field. The implosive breakdown, cavitation, and near-liquid-solid interfaces trigger particle damage, indicating enhanced mass transfer and releasing bioactive compounds from the biological matrix [84].

Ultrasonic baths (indirect sonification) or ultrasonic probes (direct sonification) can be used as devices. Controlling parameters $\mathrm{s}$ and the way the ultrasound waves impact the sample are the variations between these two. Ultrasonic baths operate at $40-50 \mathrm{kHz}$ frequencies and $50-500 \mathrm{~W}$ power, but ultrasonic probes can only function at $20 \mathrm{kHz}$ frequencies. The samples are submerged in the ultrasonic bath while the ultrasonic probe is embedded [85].

Equipment costs are lesser than other alternative reduction methods, and it is possible to use a wide range of solvents. The UAE works at low temperatures, enabling the protection of thermolabile compounds and preventing the structure from being fully destroyed. Low solvent quantities are used, and extraction working time is minimized, which makes this process an easy, cost-effective process compared to conventional processes [84].

\subsubsection{Solvent extraction.}

Solvent extraction has become an ideal form of oil extraction due to its greater percentage of oil recovery. In the past, solvent extraction processes have been used to properly remove lipid from green algae collected from the open pond system and recover almost all oils, leaving just $0.5 \%$ to $0.7 \%$ of residual oil behind. The use of organic lipid extraction solvents 
requires energy-consuming distillation after extraction to isolate lipid from solvents after extraction [86].

Non-polar solvents named hexane, benzene, toluene, diethyl ether, chloroform, and polar solvents named methanol, acetone, ethyl acetate, and ethanol are used to extract lipids from algal biomass. Non-polar solvents disrupt the hydrophobic interactions among non-polar and neutral lipids present in the biomass of algae. The solvents often used to recover lipid from microalgae biomass are n-hexane, ethanol, 1-butanol, dimethyl ether, and mixtures of chloroform/methanol, n-hexane/ethanol n-hexane/isopropanol, n-hexane/2-propanol, methanol/1-ethyl-3-methylimidazol methyl sulfate, methylene chloride/methanol, dichloroethane/methanol, dichloroethane/ethanol and acetone/dichloromethane [86]. Some studies have used various methods for lipid extraction from the dry biomass of Chlorella pyrenoidosa, named as Soxhlet extraction, magnetic stirring, and ultrasonic bath with five solvent systems, including chloroform and methanol mixtures $(2: 1 \mathrm{v} / \mathrm{v})$, methanol, chloroform, ethanol, and hexane. They stated that the chloroform/methanol mixture used as a solvent for extraction yields more microalgae lipids than other solvents [79].

\subsubsection{Supercritical fluid extraction.}

For the extraction of essential oils from plants and also for lipid extraction from microalgae, supercritical fluid extraction has been applied. This extraction method is based on the concept of fluid extraction under supercritical conditions, with the properties of both liquids and gases increasing the temperature and pressure above their critical point. The fluid density is comparable to the values used for liquids, whereas the fluid's viscosity is identical to the gas value. Because of its nontoxicity, safety, and reduced cost, carbon dioxide $\left(\mathrm{CO}_{2}\right)$ is the most used solvent for this process. Because of the low viscosity and greater diffusion coefficient, the main benefit of supercritical fluid is higher mass transfer. Supercritical $\mathrm{CO}_{2}$ can only remove non-polar or low polarity compounds as it is a non-polar solvent, but by putting very little quantities of polar co-solvents, including ethanol or methanol, the extraction of polar compounds can be improved [84].

The solubility and selectivity of the several components in the supercritical fluid are responsible for circumstances throughout the extraction, particularly pressure and temperature. $\mathrm{CO}_{2}$ has a reduced critical temperature and pressure, which ensures that bioactive compounds are retained. There can be no degrading changes. The extracts obtained with Super criticalCO2 typically contain compound groups including fatty acids and phytosterols tocopherols, phenols, carotenoids, and triglycerides [84]. However, the energy-intensive nature of the process challenges the economic development of biofuels from microalgae through supercritical processing.

\subsubsection{Pyrolysis.}

Pyrolysis includes the direct thermal decomposition of biomass at extreme temperatures $\left(400^{\circ} \mathrm{C}-1000^{\circ} \mathrm{C}\right)$ when there is no catalyst and oxygen to create bio-oil in solids (char and coke), liquids (bio-oil), or gaseous fuels (methane and higher gaseous hydrocarbons) with a minimal oxygen supply. Two forms of pyrolysis are documented in the literature: slow (lesser operating temperature and longer duration) and rapid pyrolysis (greater operating temperature and shorter duration) [77]. The substance developed through the technique of pyrolysis is called bio-oil. In comparison to rapid pyrolysis, slow pyrolysis occasionally leads to low levels of 
bio-oil. The pyrolysis conducted at higher temperatures lacks the basic efficiency of the materials. Different results were provided by the different strains of algae, and the temperature during which pyrolysis was conducted also contributed a lot (Table 9).

Table 9. Characteristics and yield of bio-oil from the pyrolysis of micro-algae.

\begin{tabular}{|c|c|c|c|c|}
\hline Micro-algae & Catalyst & Characteristics of bio-oil & Yield of bio-oil (wt \%.) & References \\
\hline Chlorella protothecoides & - & $\begin{array}{l}\text { Free carbon emission fuel } \\
\text { production }\end{array}$ & $31.17 \%$ at $450^{\circ} \mathrm{C}$. & [77] \\
\hline Dunaliella tertiolecta & - & $\begin{array}{l}\text { Higher proportions of ester } \\
\text { and was eco- friendly }\end{array}$ & $36.9 \%$ at $360^{\circ} \mathrm{C}$. & [87] \\
\hline Cyanobacteria & $\begin{array}{l}\text { MgAl- } \\
\text { LDO/ZSM-5 }\end{array}$ & $\begin{array}{l}\text { It consists of fewer nitrogen } \\
\text { compounds and a low } \mathrm{O} / \mathrm{C} \\
\text { molar ratio }\end{array}$ & $41.1 \%$ at $550^{\circ} \mathrm{C}$. & [88] \\
\hline Chlorella vulgaris & - & $\begin{array}{l}\text { Consists of aromatic } \\
\text { compounds, fatty acids, and } \\
\text { carbohydrates }\end{array}$ & $47.7 \%$ at $550^{\circ} \mathrm{C}$. & [89] \\
\hline $\begin{array}{l}\text { Chlamydomanas } \\
\text { debaryana }\end{array}$ & $\beta$ zeolite & High hydrocarbon content. & $\begin{array}{l}43.5 \% \text { and } 43.8 \% \text { at } \\
600{ }^{\circ} \mathrm{C} \text { and } 800{ }^{\circ} \mathrm{C} \text {. }\end{array}$ & [90] \\
\hline Spirulina plantesis & - & $\begin{array}{l}\text { Low trace of Sulphur of } 0.4 \\
\text { wt } \% \text {. }\end{array}$ & $18.65 \%$ & [91] \\
\hline Chlorella vulgaris & $\begin{array}{l}\mathrm{Ni} / \mathrm{Zeolite} \\
(\mathrm{Si} / \mathrm{Al}=30)\end{array}$ & $\begin{array}{l}\text { Good concentration of } \\
\text { aromatic hydrocarbons. } \\
\text { Low oxygen content and } \\
\text { less acidic compounds }\end{array}$ & --- & [77] \\
\hline Nannochloropsis oculata & Co-Mo/gAl2O3 & $\begin{array}{l}\text { Long-chain alkanes, } \\
\text { alkenes, and polyaromatic } \\
\text { compounds are found }\end{array}$ & --- & [92] \\
\hline Saccharina Japonica & - & High aromatic content & $47 \%$ & [77] \\
\hline Duanliella Salina & - & $\begin{array}{l}\text { abundant in alkanes, } \\
\text { alkynes, and esters }\end{array}$ & $55.4 \%$ at $500^{\circ} \mathrm{C}$. & [93] \\
\hline Nannochloropsis sp. & HZSM-5 & $\begin{array}{l}\text { low oxygen and high } \\
\text { aromatics }\end{array}$ & $19.5 \%$ & [77] \\
\hline Tetraselmis sp. & - & - & $25 \%$ at $550^{\circ} \mathrm{C}$ & [94] \\
\hline U. prolifera & HY & $\begin{array}{l}\text { Long-chain nitrogen } \\
\text { compounds were present }\end{array}$ & $41.3 \%$ & [95] \\
\hline Isochrysis sp. & Li-LSX Zeolite & $\begin{array}{l}\text { High in carbon, hydrogen, } \\
\text { and the low trace of oxygen }\end{array}$ & --- & [96] \\
\hline Saccharina japonica & HZSM-5 & $\begin{array}{l}\text { Greater aromatic content } \\
\text { than aliphatics }\end{array}$ & $39.05 \%$ & [97] \\
\hline $\begin{array}{l}\text { Spirulina (Arthrospira) } \\
\text { plantensis }\end{array}$ & Fe/HMSZSM-5 & Abundant in hydrocarbons. & $37.77 \%$ & [98] \\
\hline Cryptococcus curvatus & $\mathrm{K} 2 \mathrm{CO} 3$ & $\begin{array}{l}\text { Lesser content of Sulphur } \\
\text { and nitrogen }\end{array}$ & -- & [99] \\
\hline
\end{tabular}

2.5.8. Microwave-sssisted extraction (MAE).

Microwave-Assisted Extraction is contingent on ionic conduction and dipole rotation that work directly and occur simultaneously on the molecules. Microwave heating allows molecules to consume energy where no heat is lost to the atmosphere. The disruption of cells is unavoidable because of the absorption of energy by polar molecules. Destroyed cells allow faster solid mass transfer and diffusion, whereby mass and heat transmission function therapeutically and in a similar direction [100].

In open or closed vessels, MAE can be done. Open ships operate at ambient pressure, while closed ships operate at higher than atmospheric pressure. Open vessels can be more efficient, cleaner, and it is possible to handle huge samples caused by atmospheric pressure operation. Even for thermolabile compounds, process conditions are sufficient. An advantage 
of MAE is that due to the lesser time span and quantity of solvent, this process is economical and ecologically friendly [84].

\subsubsection{Enzyme-assisted extraction.}

Food-grade digestive enzymes, including proteases and carbohydrates, can be utilized to disrupt the cell walls of natural matrice and release the cell contents by the maceration process [101]. This is especially essential for marine algae because chemically complex and heterogeneous biomolecules make up cell walls and cuticles [102]. Relevant parameters to be considered are $\mathrm{pH}$, the proportion of substrate to enzyme, temperature, the form of solvent (water or buffer with sufficient $\mathrm{pH}$ ), and agitation [83].

\subsubsection{Bio-photolysis-direct process.}

Bio-photolysis is called the act of light on a biological system, leading to the decoupling of a substrate, generally, water, to generate hydrogen. Direct bio-photolysis of $\mathrm{H}_{2}$ production is a biological protocol that utilizes solar energy and photosynthetic algae systems to transform water into chemical energy. However, direct bio photolysis gives a functioning system for hydrogen generation from water and sunlight resources, although limited by its relatively low hydrogen productivity. The creation of knowledge and technological advances in the field of hydrogen enzymes is therefore important. Electron carriers that would move to a photolysis system for bio-mimetic water prevent the inherent incompatibility of the parallel evolution of hydrogen and oxygen and sunder water into gas streams [78].

\subsubsection{Bio-photolysis-indirect process.}

Those integrating distinct stages of micro-algal photosynthesis and fermentation (indirect bio-photolysis) are the most effective approaches for future applied research work and growth. These include the fixation of $\mathrm{CO}_{2}$ in storage carbohydrates (e.g., green algae starch, cyanobacteria glycogen), accompanied by their transition to $\mathrm{H}_{2}$ by reversible hydrogenase, both in dark and possibly light-driven conditions. In indirect bio-photolysis, the issue of the sensitivity of the $\mathrm{H}_{2}$ process to $\mathrm{O}_{2}$ is normally enforced by sundering $\mathrm{O}_{2}$ and $\mathrm{H}_{2}$ [80].

In the ideal indirect bio photolysis, hydrogen is emitted as shown below:

$$
\begin{aligned}
& 12 \mathrm{H}_{2} \mathrm{O}+6 \mathrm{CO}_{2} \rightarrow \mathrm{C}_{6} \mathrm{H}_{12} \mathrm{O}_{6}+6 \mathrm{O}_{2} \\
& \mathrm{C}_{6} \mathrm{H}_{12} \mathrm{O}_{6}+12 \mathrm{H}_{2} \mathrm{O} \rightarrow 12 \mathrm{H}_{2}+6 \mathrm{CO}_{2}
\end{aligned}
$$

Based on a prefatory engineering and economic evaluation, bio photolysis procedures must attain adjacent to $10 \%$ of total solar energy conversion efficiency in order to compete with alternative renewable $\mathrm{H}_{2}$ sources, including photovoltaic electrolysis processes. These greater solar conversion efficiencies in photosynthetic $\mathrm{CO}_{2}$ fixation could be achieved by genetically minimizing the usage of light chlorophyll and other pigments harvested in microalgae. Microalgae processes powered by solar energy for biohydrogen production are theoretically huge-scale, but often require long time scale and economically high-risk processes [81].

\subsection{Algae-based fuel.}

Currently, global warming and depletion of biofuels have taken the world to consider the development of bioenergy from algal biomass. Increased access and energy protection are also crucial plans to minimize poverty. The only solution currently available to substitute the 
use and reliance on fossil fuels is developing biofuels from algae biomass. Micro-algal biomass can be utilized in developing diversified biofuels such as bio-oil, bio-methane, bio-hydrogen, bio-gas, bio-ethanol, and biodiesel.

\subsubsection{Bio-Oil.}

Thermo-chemical conversion is a process that produces bio-oil by transforming biomass into oil and carbon, and gas at very increased temperatures in the absence of oxygen. Bio-oils are somewhat related to petroleum oils, but they can be utilized as a supplement for them. Pyrolysis and thermos chemical liquefaction are the 2 major types of machinery for the production of bio-oil. Different varieties of organic composites are accumulated as lipids, proteins, and carbohydrates in bio-oil, and as contrasted to algae lipids, the yield is large. Biooil yields from microalgae have been recorded up to $41 \%$ for Spirulina, about $24 \%-45 \%$ for microalgae Scenedesmus, about 37\% for Dunaliella, and up to $49 \%$ for Desmodesmus [103].

\subsubsection{Bio-hydrogen.}

An urgent energy problem has been the diversity of biofuel sources. A great deal of emphasis has been put on bio-hydrogen production in recent years. However, due to the expensive process and low biomass concentration, large-scale development of bio-hydrogen is not yet workable. It has been documented in some studies that revealing certain types of algae to multiple ecological pressures, including depriving algae of light, may cause considerable quantities of hydrogen gas. But this technology is only at its inception, and it is possible to evolve or upgrade the method to a higher standard [104].

The three routes indicated for hydrogen production are 1. direct photolysis 2 . Indirect photolysis 3. ATP-driven pathway. Direct photolysis is only possible when the hydrogen and oxygen produced are uninterruptedly extracted. Here, photosynthesis and water splitting are related, resulting in the development of hydrogen and oxygen simultaneously, leading to greater safety risks and raising the hydrogen and oxygen separation cost. In addition, the hydrogenase enzyme used in the procedure is strongly sensitized to oxygen. Indirect mechanisms are also preferred for these purposes. In anaerobic and sulfur-limited environments, the starch present in the algae cell walls is transformed to hydrogen up to a certain degree. Cyanobacteria have been the key producers of biohydrogen by biological approach in most studies; hydrogenase and nitrogenase enzymes behave as catalysts in this procedure [103].

The single-cell green algae Chlamydomonas reinhardtii has been deeply researched for its photo-biological hydrogen production [8]. Knowing how biomass is transformed to hydrogen gas would provide chances to minimize the environmental effect of petroleum-based fuels. In order to evaluate the output of hydrogen from algae, some scientists conducted a species-selective assessment using ambient pressure microwave plasma reactor and microwave-assisted pyrolysis at different operating temperatures and utilized this knowledge to generate hydrogen development technologies [103]. In order to encourage the development of hydrogen through photosynthesis in green algal cells, Some research groups created two new systems in $C$. reinhardtii and $C$. pyrenoidosa, a bisulfite addition system [106-107] and a cell aggregation system [108], which provided viable strategies to increase the production of hydrogen photo-production from $\mathrm{H}_{2} \mathrm{O}$ using green algae. 
2.6.3. Biogas.

Compared with terrestrial crops, micro-algal biomass develops a suitable alternate origin of biogas. However, the use of algae for biogas production is associated with numerous difficulties [109]. The efficiency of biogas production has improved when algae are combined with conventional feedstocks [110]. Glucose and glycine derived from algae have been exposed to thermochemical treatment under neutral, acidic, and alkaline conditions to establish their decomposition mode and their future usage in the concurrent fermentation of bio-hydrogen and bio-methane [103].

High ECE was reached via the second part of untreated glucose/glycine bio-methane fermentation, but this procedure was completely suppressed by acid or alkaline treatment, recommending that an enhanced pre-treatment approach must be established to prevent the deprivation of fermentable components and to reach increased ECE levels [111].

A two-stage continuous co-production strategy for fermentative hydrogen and methane was produced using a $20 \mathrm{C} / \mathrm{N}$ ratio of macroalgae (Laminaria digitata) and microalgae (Arthrospira platensis), which provided improved power recovery and higher operating stability than single-stage anaerobic co-digestion of algal combinations [112]. An interconnected framework method incorporating freshwater microalgae cultivation S. Obliquus has been used to evaluate problems such as $\mathrm{CO}_{2}$ sequestration, wastewater treatment, and biogas processing for biogas generation with the treatment of piggery anaerobic digestate liquid [113]. In combination with environmental bioremediation, water-blooming cyanobacteria can be utilized for biogas processing as well. During methanogenesis, the concentration of microcystin decreases significantly, indicating that anaerobic digestion of cyanobacteria could develop biogas from renewable energy while biodegrading microcystin [103].

For example, as both a fuel and a chemical feedstock, methane is commonly used. Researchers explored the potential for bio-methane production of various feedstock, including algae, wood, grass, solid waste, and algae biomass have been proposed as a possible source for bio-methane production. The productivity of biomass algae is usually higher than that of ground plants, but its growth is altered by various nutrient constraints [103].

\subsubsection{Bioethanol.}

Bioethanol production from algae has obtained significant value because of its greater biomass productivity, diversity, diverse chemical composition, and increased photosynthetic rates of these species. Algae are the optimal source of bioethanol development because of the abundance of carbohydrates/polysaccharides and thin cellulose walls [114].

Most of the micro-algae carbohydrates are polysaccharides, like starch and cellulose. In the complex multi-layered cell walls of microalgae, high levels of polysaccharides can accumulate, allowing them a favored raw material for the production of bioethanol for fermentation [109].

Researchers investigated the ability of Chlorococcum littorale marine green algae to develop ethanol under dark fermentation, and within 24 hours, approximately 27 percent of starch found in algal cells was used at $25^{\circ} \mathrm{C}$ and also assessed the potential of the feedstock of algal biomass to generate bioethanol and to facilitate its use as a renewable biofuel to provide a convenient alternative. Dunaliella, Chlorella, Chlamydomonas, Arthrospira, Sargassum, Spirulina, Gracilaria, Prymnesium parvum, Euglena gracilis, and Scenedesmus are examples of green algae engaged for bioethanol. Yoza and Masutani have studied that up to 49 percent 
of sugars from algal biomass can be released by acid pre-treatment, while enzymatic hydrolysis can discharge up to 20 percent of sugars contingent on their dry weight. Ethanol yields for Ulva lactuca were decreased even after sugar release after hydrothermal pre-treatment, but mechanical pressing increased the yield to $0.14 \mathrm{gg}-1$ dry matter due to the removal of inhibitors produced during fermentation [114-115].

Brown algae are known as a significant feedstock for the development of ethanol among all algae (brown-green, red algae). Because of their greater carbohydrate content and simplicity of cultivation, they can be transformed into ethanol via fermentation. Laminaria hyperborean generates yeast-fermented laminarin and mannitol to create a significant amount of ethanol. Red algae fermentation has also been documented to have been converted into sugars using acid hydrolysis agar, but ethanol yields were poor at the maximum theoretical yield of up to $45 \%$. Depending on the algae genera and various methods for pre-treatment and hydrolysis, the fermentation of seaweed yields ethanol between 0.08 and $0.12 \mathrm{~kg} \cdot \mathrm{kg}^{-1}$ dry seaweed [114]. Scientists have realized from their studies that the processing of brown seaweed ethanol demands high ethanol yields for the industrial process and the use of all seaweed additives for non-fuel products. Bioethanol is industrially utilized in $86 \%$ of cars sold in Brazil as ethanol or as a combination of ethanol and petroleum. But there are still many bioethanol drawbacks named low vapor pressure, lesser energy density, and lesser luminosity of the flame [103].

Before processing bioethanol, most micro-algal biomass requires enzymatic hydrolysis. Algal bioethanol overcomes the main disadvantages of first-generation (from food crops including maize [Zea mays], rice or sugarcane) and second-generation (from lignocellulosic feedstock) bioethanol [116]. Under suitable culture conditions, several algae organisms generate greater quantities of ethanol if the substrates can be fermented [117-118].

\subsubsection{Biodiesel.}

The production cost of biodiesel contingent largely on the type of raw material used as $50-85 \%$ of the overall fuel price is a major consideration. Evaluation of feedstock is essential for the development of cost-effective biodiesel in terms of efficiency, quality, and utilization of by-products that should be taken into account. Transesterification is called the method of converting raw material lipids, basically, triacylglycerols/free fatty acids, into non-toxic and environmentally friendly biodiesel. In the form of fatty acid alkyl esters, crude algal oil of high viscosity is transformed into lower molecular weight components. During the transesterification process in the presence of a catalyst, crude oil reacts with alcohol; ideally, methanol and methyl esters of fatty acid (FAME) are generated along with glycerol as the final product. Acid catalyst application has been considered beneficial, but alkali catalyst is commercially used up to 400 times compared to acid catalyst due to its rapid existence. Chlorella vulgaris and Chlorella protothecoides are two significant species; they consist of greater oil content have been investigated by several workers for the development of biodiesel [114].

Microalgal biodiesel consists predominantly of unsaturated fatty acids. A mixture of different algae is found in the algal biomass from wastewater, and several fatty acid profiles can therefore be generated. Biodiesel from the algae Chlorella sp., Euglena sp., Spirogyra sp., Scenedesmus sp., Desmodesmus sp., Pseudokirchneriella sp., Phormidium sp. and Nitzschia $s p$. were developed by Bjerk using a collection of different systems [103]. Throughout cultivation, micro-algal growth and lipid accumulation do not relate, which can hinder the overall productivity of lipids. Regulation of both biomass and lipid content is essential for the 
economic practicability of micro-algal-based biofuel development. Another major challenge in biofuel development is developing successful methods for extracting micro-algal biomass from the culture broth. In order to further reduce the cost of microalgae harvesting and the production of biodiesel, researchers have concentrated on micro-algae harvesting technologies, including magnetic separation technology, $\mathrm{pH}$-induced flocculation, and ultrafiltration [103].

In addition to the production of biofuels, microalgae seem to be a prospective renewable source that could be utilized for various industrial applications, including cosmetics, pharmaceuticals, aquaculture, animal feed, bio-fertilizer, human food, etc. [119]. Micro-algae are also a very good source of natural products which are responsible for various bio-activities.

\subsubsection{Biofuel applications.}

Table 10 summarises the most suitable scenarios for the bio-fuels to be adopted under the current scenarios. The information delineates that the application of each type of bio-fuel has some distinct differences from the rest.

Table 10. Biofuels and best-suited scenarios for them to be used.

\begin{tabular}{|c|c|c|}
\hline Bio-fuels & Best suited scenarios & References \\
\hline Bio-oil & $\begin{array}{l}\text { Used in blast furnace } \\
\text { Used for on-site and off-site power production } \\
\text { Used as a soil amendment }\end{array}$ & [120] \\
\hline Bio-hydrogen & $\begin{array}{l}\text { As fuel in vehicles for transportation } \\
\text { E.g., Hydrogen-powered cars } \\
\text { Used in combustion engines }\end{array}$ & [121] \\
\hline Biogas & $\begin{array}{l}\text { Used as alternative fuels in vehicles and power production } \\
\text { Used as fuel in fuel cell technologies including polymer } \\
\text { electrolyte membrane fuel cell (PEMFC), phosphoric acid fuel } \\
\text { cell (PAFC), alkaline fuel cell (AFC), solid oxide fuel cells } \\
\text { (SOFC), molten carbonate fuel cell (MCFC) and direct methanol } \\
\text { fuel cell (DMFC). }\end{array}$ & [122] and [123] \\
\hline Bioethanol & $\begin{array}{l}\text { Used in advanced compression ignition engines, including dual- } \\
\text { fuel combustion and RCCI engine }\end{array}$ & [124] \\
\hline Biodiesel & $\begin{array}{l}\text { Used in Automotive diesel engines } \\
\text { Used as a heat generator } \\
\text { Utilized in railway usage and aircraft usage }\end{array}$ & [125-127] \\
\hline
\end{tabular}

\subsection{Recommendations for future developments.}

Compared to other general biomass, the microorganism can generate higher biofuel amounts [128]. Importantly, algae are a great bonus for the community for the production of various biofuels. Algal oil is unfit for human consumption and thus does not have to react to disputes regarding food affordability. Greater lipids/fatty acids present in algae allow it to turn them into biofuel successfully [77]. Potentially, micro-algal lipids can be transformed into biofuels, whereas micro-algal biomass can be used to generate useful products, including carbohydrates, polyunsaturated fatty acids, and proteins, and all can be polished for a range of applications. Microalgae is indeed an invaluable pillar of biofuels and bio-based chemical products [2].

As a renewable and carbon-neutral source of transport fuel, algal biofuels remain in their possession. Different possibilities of environmentally friendly and replicable micro-algal processes as biofuels have been demonstrated, but major changes are needed in production's economics and power necessities. Improvements can be accomplished only by increasing efficiency, reducing costs, meeting energy demand, and applying the bio-refinery principle 
(production of algal co-products) [114]. The overall aim of this present work can be accomplished by integrating both biological and engineering frameworks.

The big issues that are actually being tackled are [2,114]:

- Boosting production in huge scale outdoor site cultures.

- Ensuring the quality of algal cultures by preventing spoilage by predators and other algal organisms.

- Regulation of temperature changes and minimize water loss due to evaporation while controlling the supply of light and $\mathrm{CO}_{2}$.

- Implementing reliable and cost-effective models to overcome high implementation and operating expenses.

- Strengthening resource efficiency and increasing productivity in the bio-refinery method, thus generating useful co-products.

- Reducing ecological impact via the recycling of water, energy, and nutrients

Various strategies could help in overcoming the challenges in the process of developing biofuels from micro-algal bio-mass.

- Choosing microalgae/cyanobacteria strains depending on the required products that can withstand temperature stress and thrive easily in the medium.

- Choosing optimal conditions can boost the effectiveness of the desired commodity, and using an effective and economically sustainable microalgae cultivation method can increase the performance of biomass.

- Creation of a highly effective and low-cost downstream process that can dramatically minimize operating costs.

- The use of combined processes and techniques for the extraction of value-added products is a mixture of new techniques that can help handle the conflicts mentioned above [2].

In order to boost energy quality and efficiency, more research effects need to be oriented towards the integration of upstream and downstream biomass slurry operations. By changing the parameters and process requirements for the recycling of nutrients, nutrient deficiencies can be remedied. The possibility to recycle nutrients can be one of the major advantages of microalgae farming over traditional algae farming if technical problems to the recycling of algae nutrients can be managed. Therefore, it is essential to establish an efficient and sustainable treatment system that can recycle nutrients from biofuel algae residues to be used in the growth of algae [10].

In addition, it is important to improve the performance of algal seeds so that algal cells gather a greater quantity of organic matter, which can be used for the preparation of biofuels and establish methods for collecting algae effectively and inexpensively, and to diminish energy consumption during the preparation process of biofuels. The concept of a synthetic "cell factory" comprising photosynthetic microalgae via synthetic biology technologies is likely to be an important move toward the industrialization of micro-algae biofuels. Intensive research efforts should also work towards making major advances in the following areas [103]:

- Breeding technologies that are suitable for cost effective production utilizing good quality germplasm resources especially, algal seeds with greater lipid content and strong resistance to stress.

- High-scale culture techniques, including high-density micro algal culture and effective lipid processing, facilitated by external cues, synthetic biology, and metabolic 
engineering to stimulate the supply of micro algal energy materials and to get high performance.

- Primary algal processing and medium recovery technologies. In specific waste materials, including waste-water and waste gas, could be recycled in order to reduce costs. Micro-algal biofuels that generate higher value-added products could also be produced.

Microalgae genetic engineering is at the beginning stages of producing robust microalgal strains to increase the economic viability of algal processes. The biotechnological tactic to engineer micro-algal strains to enhance the performance has been encouraged by the developments in high-throughput technologies and molecular biology methods. Future research should concentrate on producing purpose-based, robust bioengineered strains with increased photosynthetic efficiency, increased $\mathrm{CO}_{2}$ fixation, and greater biomass productivty. While genetic engineering of microalgae has the boundless capacity to develop the economics of the process, it is restricted primarily because of the lack of genetic knowledge available for robust and commercially suitable strains. In recent years, prompt developments in DNA synthesis, tools and approaches for genetic manipulation, and the availability of functional genomes have increased the probabilities of superior engineering of composite functional microalgae. However, the lack of the principles of genetic strain design is still limiting the advancement in this field [129].

In separate processes or as a by-product of biofuel generation, a wide range of non-fuel products can be developed with microalgae. Health and medical supplements [130-132], Fucoxanthin [133-135], anti-cancer drugs [136-138], various lipids [139-141], fertilizers [17, 142-143] are few of them. In evaluating the biofuel potential of microalgae, it is essential to assess these other products as either a completing factor, if they are a by-product of biofuel generation, or a competing factor if they are completely different processes. Comparing the cost-time benefits of biofuel extraction of microalgae vs. other microalgae-based products will make the final decision on the investment of microalgae-based biofuel industry in a given country.

\section{Conclusions}

Microalgae applications on a wide scale cannot be contemplated unless their biomass yield is boosted or combined with other technologies. Microalgae provide favorable properties to recommend them as substitute feedstock for numerous bio-refinery applications. However, the drawbacks of microalgae productivity and the disadvantages of bioprocessing technologies make it impractical for microalgae biomass to be completely exploited. In the field of processing algae into perfect power, the challenges are very enthralling. Algal biofuel works miracles in engines, yet a thorough review of the fuel compatibility requirements is necessary. After all, we still have a long way to go to make algal biofuel an option instead of fossil fuel that is commercially viable [144]. While many micro-algal products have been marketed, most of them are in the industrialization phase, and only a few pilot studies have been carried out. A wide-scale preparatory system for micro-algal energy still needs to be defined. Detailed research efforts should emphasize advancements in microalgae breeding, large-scale cultivation, effective selection of algae, and medium recovery, particularly, reducing the cost of producing microalgal biofuels. Work is needed to build up current technologies further, and comprehensive investigation is necessary to assess the potential of microalgae as a successful biotechnology feedstock. For instance, to accelerate microalgae's productivity, more advanced 
cultivation techniques need to be developed, and advanced biotechnology, including gene editing, can be tried to raise the development of bioactive compounds from the strains of microalgae. Techno-economic evaluation and life-cycle assessment studies should also be conducted to verify co-processing models' economic viability and environmental sustainability.

\section{Funding}

This research received no external funding.

\section{Acknowledgments}

The authors would like to thank the Department of Plant Sciences, Faculty of Science, University of Colombo, Sri Lanka, and the School of Electrical and Information Engineering, University of Witwatersrand, South Africa, for providing excellent facilities to make this study a success.

\section{Conflicts of interest}

The authors declare no conflict of interest.

\section{References}

1. Tan, J.; Lee, S.; Chew, K.; Lam, M.; Lim, J.; Ho, S.; Show, P. A review on microalgae cultivation and harvesting, and their biomass extraction processing using ionic liquids. Bioengineered 2020, 11, 116-129, https://doi.org/10.1080/21655979.2020.1711626.

2. Rizwan, M.; Mujtaba, G.; Memon, S.; Lee, K.; Rashid, N. Exploring the potential of microalgae for new biotechnology applications and beyond: A review. Renewable and Sustainable Energy Reviews 2018, 92, 394-404, https://doi.org/10.1016/j.rser.2018.04.034.

3. Pikoli, M.; Sari, A.; Solihat, N.; Permana, A. Characteristics of tropical freshwater microalgae Micractinium conductrix, Monoraphidium sp. and Choricystis parasitica, and their potency as biodiesel feedstock. Heliyon 2019, 5, 12, E02922, https://doi.org/10.1016/j.heliyon.2019.e02922.

4. Han, P.; Lu, Q.; Fan, L.; Zhou, W. A Review on the Use of Microalgae for Sustainable Aquaculture. Applied Sciences 2019, 9, 11, 2377, https://doi.org/10.3390/app9112377.

5. Khan, M.; Shin, J.; Kim, J. The promising future of microalgae: current status, challenges, and optimization of a sustainable and renewable industry for biofuels, feed, and other products. Microbial Cell Factories 17, 2018, 36, https://doi.org/10.1186/s12934-018-0879-x.

6. Kotasthane, T. Potential of Microalgae for Sustainable Biofuel Production. Journal of Marine Science: Research and Development 2017, 07, https://doi.org/10.4172/2155-9910.1000223.

7. Randrianarison, G.; Ashraf, M. Microalgae: a potential plant for energy production. Geology, Ecology, And Landscapes, 2017, Volume 1, 104-120, https://doi.org/10.1080/24749508.2017.1332853.

8. Zhan, J.; Rong, J.; Wang, Q. Mixotrophic cultivation, a preferable microalgae cultivation mode for biomass/bioenergy production, and bioremediation, advances and prospect. International Journal of Hydrogen Energy 2017, 42, 8505-8517, https://doi.org/10.1016/j.ijhydene.2016.12.021.

9. Onen Cinar, S.; Chong, Z.; Kucuker, M.; Wieczorek, N.; Cengiz, U.; Kuchta, K. Bioplastic Production from Microalgae: A Review. International Journal of Environmental Research and Public Health 2020, 17, 3842, https://doi.org/10.3390/ijerph17113842.

10. Show, P.; Tang, M.; Nagarajan, D.; Ling, T.; Ooi, C.; Chang, J. A Holistic Approach to Managing Microalgae for Biofuel Applications. International Journal of Molecular Sciences, 2017, 18, 215, https://doi.org/10.3390/ijms18010215.

11. Gomez-Zavaglia, A.; Prieto Lage, M.; Jimenez-Lopez, C.; Mejuto, J.; Simal-Gandara, J. The Potential of Seaweeds as a Source of Functional Ingredients of Prebiotic and Antioxidant Value. Antioxidants 2019, 8, 406, https://doi.org/10.3390/antiox8090406.

12. WoRMS - World Register of Marine Species. Marinespecies.org. (2021). Retrieved 15, July 2020, from https://www.marinespecies.org/. 
13. Dolganyuk, V.; Belova, D.; Babich, O.; Prosekov, A.; Ivanova, S.; Katserov, D. et al. Microalgae: A Promising Source of Valuable Bio products. Biomolecules 2020, 10, 1153; https://doi.org/10.3390/biom10081153.

14. Andrade, L. Chlorella and Spirulina Microalgae as Sources of Functional Foods, Nutraceuticals, and Food Supplements; an Overview. MOJ Food Processing \& Technology 2018, 6, https://doi.org/10.15406/mojfpt.2018.06.00144.

15. Elshout, P.; van der Velde, M.; van Zelm, R.; Steinmann, Z.; Huijbregts, M. Comparing greenhouse gas footprints and payback times of crop-based biofuel production worldwide. Biofuels 2019, 1-7, https://doi.org/10.1080/17597269.2019.1630056.

16. Demirbas, A.; Edris, G. Biofuels production from microalgae by liquefaction and supercritical water pyrolysis. Energy Sources, Part A: Recovery, Utilization, and Environmental Effects 2017, 39, 827-834, https://doi.org/10.1080/15567036.2016.1269143.

17. Chittora, D.; Meena, M.; Barupal, T.; Swapnil, P.; Sharma, K. Cyanobacteria as a source of biofertilizers for sustainable agriculture. Biochemistry and Biophysics Reports 2020, 22, 100737 , https://doi.org/10.1016/j.bbrep.2020.100737.

18. Barkia, I., Saari, N., Manning, S. Microalgae for High-Value Products towards Human Health and Nutrition. Marine Drugs 2019, 17, 304, https://doi.org/10.3390/md17050304.

19. Caporgno, M.; Mathys, A. Trends in Microalgae Incorporation into Innovative Food Products with Potential Health Benefits. Frontiers in Nutrition 2018, 5, https://doi.org/10.3389/fnut.2018.00058.

20. Abu-Galiyun, E.; Huleihel, M.; Levy-Ontman, O. Antiviral bioactivity of renewable polysaccharides against Varicella Zoster. Cell Cycle 2019, 18, 3540-3549, https://doi.org/10.1080/15384101.2019.1691363.

21. Cano, M.; Holland, S.; Artier, J.; Burnap, R.; Ghirardi, M.; Morgan, J.; Yu, J. Glycogen Synthesis and Metabolite Overflow Contribute to Energy Balancing in Cyanobacteria. Cell Reports 2018, 23, 667-672, https://doi.org/10.1016/j.celrep.2018.03.083.

22. Cian, R.; Drago, S.; de Medina, F.; Martínez-Augustin, O. Proteins and Carbohydrates from Red Seaweeds: Evidence for Beneficial Effects on Gut Function and Microbiota. Marine Drugs 2015, 13, 5358-5383, https://doi.org/10.3390/md13085358.

23. Hussian, A. The Role of Microalgae in Renewable Energy Production: Challenges and Opportunities. In Marine Ecology - Biotic and Abiotic Interactions 2018, Open access peer-reviewed chapter, https://doi.org/10.5772/intechopen.73573.

24. Han, S.; Jin, W.; Tu, R.; Wu, W. Biofuel production from microalgae as feedstock: current status and potential. Critical Reviews in Biotechnology 2014, 35, 255-268, https://doi.org/10.3109/07388551.2013.835301.

25. Béchet, Q.; Laviale, M.; Arsapin, N.; Bonnefond, H.; Bernard, O. Modelling the impact of high temperatures on microalgal viability and photosynthetic activity. Biotechnology for Biofuels 2017, 10, https://doi.org/10.1186/s13068-017-0823-z.

26. Covarrubias, Y.; Cantoral-Uriza, E.; Casas-Flores, J.; García-Meza, J. Thermophile mats of microalgae growing on the woody structure of a cooling tower of a thermoelectric power plant in Central Mexico. Revista Mexicana De Biodiversidad 2016, 87, 277-287, https://doi.org/10.1016/j.rmb.2016.04.001.

27. Singh, S.; Singh, P. Effect of temperature and light on the growth of algae species: A review. Renewable and Sustainable Energy Reviews 2015, 50, 431- 444, https://doi.org/10.1016/j.rser.2015.05.024.

28. Lurling, M.; Eshetu, F.; Faassen, E.; Kosten, S.; Huszar, V. Comparison of cyanobacterial and green algal growth rates at different temperatures. Freshwater Biology 2012, 58, 552-559, https://doi.org/10.1111/j.13652427.2012.02866.x.

29. Sharma, A.; Kumar, V.; Shahzad, B.; Ramakrishnan, M.; Singh Sidhu, G.; Bali, A. et al. Photosynthetic Response of Plants under Different Abiotic Stresses: A Review. Journal of Plant Growth Regulation 2019, 39, 509-531, https://doi.org/10.1007/s00344-019-10018-x.

30. Qiu, R.; Gao, S.; Lopez, P.; Ogden, K. Effects of $\mathrm{pH}$ on cell growth, lipid production and $\mathrm{CO}_{2}$ addition of microalgae Chlorella sorokiniana. Algal Research, 2017, 28, 192-199, https://doi.org/10.1016/j.algal.2017.11.004.

31. He, L.; Chen, Y.; Wu, X.; Chen, S.; Liu, J.; Li, Q. Effect of Physical Factors on the Growth of Chlorella Vulgaris on Enriched Media Using the Methods of Orthogonal Analysis and Response Surface Methodology. Water 2020, 12, 34, https://doi.org/10.3390/w12010034. 
32. Orefice, I.; Musella, M.; Smerilli, A.; Sansone, C.; Chandrasekaran, R.; Corato, F.; Brunet, C. Role of nutrient concentrations and water movement on diatom's productivity in culture. Scientific Reports 2019, 9, https://doi.org/10.1038/s41598-018- 37611-6.

33. Gardner-Dale, D.; Bradley, I.; Guest, J. Influence of solids residence time and carbon storage on nitrogen and phosphorus recovery by microalgae across diel cycles. Water Research 2017, 121, 231-239, https://doi.org/10.1016/j.watres.2017.05.033.

34. Yang, L.; Chen, J.; Qin, S.; Zeng, M.; Jiang, Y.; Hu, L. et al. Growth and lipid accumulation by different nutrients in the microalga Chlamydomonas reinhardtii. Biotechnology for Biofuels 2018, 11, https://doi.org/10.1186/s13068-018-1041-z.

35. Karpiński, T.; Adamczak, A. Fucoxanthin—an Antibacterial Carotenoid. Antioxidants 2019, 8, 239, https://doi.org/10.3390/antiox8080239.

36. Hashemi, A.; Moslemi, M.; Pajoum Shariati, F.; Delavari Amrei, H. Beta-carotene production within Dunaliella salina cells under salt stress condition in an indoor hybrid helical-tubular photo bioreactor. The Canadian Journal of Chemical Engineering 2019, 98, 69-74, https://doi.org/10.1002/cjce.23577.

37. Singh, G.; Patidar, S. Microalgae harvesting techniques: A review. Journal of Environmental Management 2018, 217, 499-508, https://doi.org/10.1016/j.jenvman.2018.04.010.

38. Zhao, F.; Chu, H.; Zhang, Y.; Jiang, S.; Yu, Z.; Zhou, X.; Zhao, J. Increasing the vibration frequency to mitigate reversible and irreversible membrane fouling using an axial vibration membrane in microalgae harvesting. Journal of Membrane Science 2017, 529, 215-223, https://doi.org/10.1016/j.memsci.2017.01.039.

39. Giménez, J.; Bouzas, A.; Carrere, H.; Steyer, J.; Ferrer, J.; Seco, A. Assessment of cross-flow filtration as microalgae harvesting technique prior to anaerobic digestion: Evaluation of biomass integrity and energy demand. Bioresource Technology 2018, 269, 188-194, https://doi.org/10.1016/j.biortech.2018.08.052.

40. Wenten, I.; Steven, S., Dwiputra; A., Khoiruddin; Hakim, A. From lab to full-scale ultrafiltration in microalgae harvesting. Journal of Physics: Conference Series 2017, 877, 012002, https://doi.org/10.1088/1742-6596/877/1/012002.

41. Marbelia, L.; Mulier, M.; Vandamme, D.; Muylaert, K.; Szymczyk, A.; Vankelecom, I. Polyacrylonitrile membranes for microalgae filtration: Influence of porosity, surface charge and microalgae species on membrane fouling. Algal Research 2016, 19, 128-137, https://doi.org/10.1016/j.algal.2016.08.004.

42. Eliseus, A.; Bilad, M.; Nordin, N.; Putra, Z.; Wirzal, M. Tilted membrane panel: A new module concept to maximize the impact of air bubbles for membrane fouling control in microalgae harvesting. Bio resource Technology 2017, 241, 661-668, https://doi.org/10.1016/j.biortech.2017.05.175.

43. Ndikubwimana, T.; Zeng, X.; Murwanashyaka, T.; Manirafasha, E.; He, N.; Shao, W.; Lu, Y, Harvesting of freshwater microalgae with microbial bioflocculant: a pilot-scale study. Biotechnology for Biofuels 2016, 9 , https://doi.org/10.1186/s13068-016-0458-5.

44. Abdul Hamid, S.; Lananan, F.; Khatoon, H.; Jusoh, A.; Endut, A. A study of coagulating protein of Moringa oleifera in microalgae bio-flocculation. International Biodeterioration \& Biodegradation 2016, 113, 310317, https://doi.org/10.1016/j.ibiod.2016.03.027.

45. Xu, K.; Zou, X.; Wen, H.; Xue, Y.; Zhao, S.; \& Li, Y. Buoy-bead flotation harvesting of the microalgae Chlorella vulgaris using surface-layered polymeric microspheres: A novel approach. Bio resource Technology 2018, 267, 341-346, https://doi.org/10.1016/j.biortech.2018.07.065.

46. Zhang, X.; Wang, L.; Sommerfeld, M.; Hu, Q. Harvesting micro algal biomass using magnesium coagulationdissolved air flotation. Biomass and Bioenergy 2016, 93, 43-49, https://doi.org/10.1016/j.biombioe.2016.06.024.

47. Kim, D.; Lee, K.; Lee, J.; Lee, Y.; Han, J.; Park, J.; Oh, Y. Acidified-flocculation process for harvesting of microalgae: Coagulant reutilization and metal-free-microalgae recovery. Bio resource Technology 2017, 239, 190-196, https://doi.org/10.1016/j.biortech.2017.05.021.

48. Alkarawi, M.; Caldwell, G.; Lee, J. Continuous harvesting of microalgae biomass using foam flotation. Algal Research 2018, 36, 125-138, https://doi.org/10.1016/j.algal.2018.10.018.

49. Luo, S.; Griffith, R.; Li, W.; Peng, P.; Cheng, Y.; Chen, P. et al. A continuous flocculants-free electrolytic flotation system for microalgae harvesting. Bio resource Technology 2017, 238, 439-449, https://doi.org/10.1016/j.biortech.2017.04.061.

50. Oliveira, G.; Carissimi, E.; Monje-Ramírez, I.; Velasquez-Orta, S.; Rodrigues, R.; Ledesma, M. Comparison between coagulation-flocculation and ozone-flotation for Scenedesmus micro algal biomolecule recovery and 
nutrient removal from wastewater in a high-rate algal pond. Bio resource Technology 2018, 259, 334-342, https://doi.org/10.1016/j.biortech.2018.03.072.

51. Hattab, M. Microalgae Harvesting Methods for Industrial Production of Biodiesel: Critical Review and Comparative Analysis. Journal of Fundamentals of Renewable Energy and Applications 2015, 5, https://doi.org/10.4172/2090-4541.1000154.

52. Soomro, R.; Ndikubwimana, T.; Zeng, X.; Lu, Y.; Lin, L.; Danquah, M. Development of a Two-Stage Microalgae Dewatering Process - A Life Cycle Assessment Approach. Frontiers in Plant Science 2016, 7, https://doi.org/10.3389/fpls.2016.00113.

53. Bracharz, F.; Helmdach, D.; Aschenbrenner, I.; Funck, N.; Wibberg, D.; Winkler, A. et al. Harvest of the Oleaginous Microalgae Scenedesmus obtusiusculus by Flocculation from Culture Based on Natural Water Sources. Frontiers in Bioengineering and Biotechnology 2018, 6, https://doi.org/10.3389/fbioe.2018.00200.

54. Chatsungnoen, T.; Chisti, Y. Harvesting microalgae by flocculation-sedimentation. Algal Research 2016, 13, 271-283, https://doi.org/10.1016/j.algal.2015.12.009.

55. Rinanti, A.; Purwadi, R. Harvesting of freshwater microalgae biomass by Scenedesmus sp. as bioflocculant. IOP Conference Series: Earth and Environmental Science 2018, 106, 012087, https://doi.org/10.1088/17551315/106/1/012087.

56. Nguyen, T.; Le, T.; Show, P.; Nguyen, T.; Tran, M.; Tran, T.; Lee, S. Bio flocculation formation of microalgae-bacteria in enhancing microalgae harvesting and nutrient removal from wastewater effluent. Bio resource Technology 2019, 272, 34-39, https://doi.org/10.1016/j.biortech.2018.09.146.

57. Pugazhendhi, A.; Shobana, S.; Bakonyi, P.; Nemestóthy, N.; Xia, A.; Banu J, R.; Kumar, G. A review on chemical mechanism of microalgae flocculation via polymers. Biotechnology Reports 2019, 21, e00302, https://doi.org/10.1016/j.btre.2018.e00302.

58. Zhu, L.; Li, Z.; Hiltunen, E. Microalgae Chlorella vulgaris biomass harvesting by natural flocculant: effects on biomass sedimentation, spent medium recycling and lipid extraction. Biotechnology for Biofuels 2018, 11, https://doi.org/10.1186/s13068-018-1183-z.

59. Laamanen, C.; Ross, G.; Scott, J. Flotation harvesting of microalgae. Renewable and Sustainable Energy Reviews 2016, 58, 75-86, https://doi.org/10.1016/j.rser.2015.12.293.

60. Ndikubwimana, T.; Chang, J.; Xiao, Z.; Shao, W.; Zeng, X.; Ng, I.; Lu, Y. Flotation: A promising microalgae harvesting and dewatering technology for biofuels production. Biotechnology Journal 2016, 11, 315-326, https://doi.org/10.1002/biot.201500175.

61. Kucmanová, A.; Gerulová, K. Microalgae Harvesting: A Review. Research Papers Faculty of Materials Science and Technology Slovak University of Technology 2019, 27, 129-143, https://doi.org/10.2478/rput2019-0014.

62. Saxena, P., Harish. Nano ecotoxicological Reports of Engineered Metal Oxide Nanoparticles on Algae. Current Pollution Reports 2018, 4, 128-142, https://doi.org/10.1007/s40726-018-0088-6.

63. Seo, J.; Kim, M.; Lee, K.; Lee, Y.; Na, J.; Jeon, S. et al. Multifunctional Nanoparticle Applications to Micro algal Bio refinery. Nanotechnology for Bioenergy and Biofuel Production 2016, 59-87, https://doi.org/10.1007/978-3-319-45459-7_4.

64. Jiang, B.; Lian, L.; Xing, Y.; Zhang, N.; Chen, Y.; Lu, P.; Zhang, D. Advances of magnetic nanoparticles in environmental application: environmental remediation and (bio) sensors as case studies. Environmental Science and Pollution Research 2018, 25, 30863-30879, https://doi.org/10.1007/s11356-018-3095-7.

65. Bharte, S.; Desai, K. Harvesting Chlorella species using magnetic iron oxide nanoparticles. Phycological Research 2018, 67, 128-133, https://doi.org/10.1111/pre.12358.

66. Fraga-García, P.; Kubbutat, P.; Brammen, M.; Schwaminger, S.; Berensmeier, S. Bare Iron Oxide Nanoparticles for Magnetic Harvesting of Microalgae: From Interaction Behaviour to Process Realization. Nanomaterials 2018, 8, 292, https://doi.org/10.3390/nano8050292.

67. Khalid, M. Nanotechnology and chemical engineering as a tool to bioprocess microalgae for its applications in therapeutics and bio resource management. Critical Reviews in Biotechnology 2019, 40, 46-63, https://doi.org/10.1080/07388551.2019.1680599.

68. Wang, S.; Stiles, A.; Guo, C.; Liu, C. Harvesting microalgae by magnetic separation: A review. Algal Research 2015, 9, 178-185, https://doi.org/10.1016/j.algal.2015.03.005.

69. Liu, P.; Zhang, H.; Wang, T.; Yang, W.; Hong, Y.; Hou, Y. Functional graphene-based magnetic nanocomposites as magnetic flocculent for efficient harvesting of oleaginous microalgae. Algal Research 2016, 19, 86-95, https://doi.org/10.1016/j.algal.2016.07.008. 
70. Mathimani, T., Mallick, N. A comprehensive review on harvesting of microalgae for biodiesel - Key challenges and future directions. Renewable and Sustainable Energy Reviews 2018, 91, 1103-1120, https://doi.org/10.1016/j.rser.2018.04.083.

71. Wang, T.; Yang, W.; Hong, Y.; Hou, Y. Magnetic nanoparticles grafted with amino-riched dendrimer as magnetic flocculant for efficient harvesting of oleaginous microalgae. Chemical Engineering Journal 2016, 297, 304-314, https://doi.org/10.1016/j.cej.2016.03.038.

72. Liu, P.; Wang, T.; Yang, Z.; Hong, Y.; Hou, Y. Long-chain poly-arginine functionalized porous $\mathrm{Fe}_{3} \mathrm{O}_{4}$ microspheres as magnetic flocculent for efficient harvesting of oleaginous microalgae. Algal Research 2017, 27, 99-108, https://doi.org/10.1016/j.algal.2017.08.025.

73. Gerulová, K.; Bartošová, A.; Blinová, L.; Bártová, K.; Dománková, M.; Garaiová, Z.; Palcut, M. Magnetic Fe3O4-polyethyleneimine nanocomposites for efficient harvesting of Chlorella zofingiensis, Chlorella vulgaris, Chlorella sorokiniana, Chlorella ellipsoidea and Botryococcus braunii. Algal Research 2018, 33, 165-172, https://doi.org/10.1016/j.algal.2018.05.003.

74. Yang, Y.; Hou, J.; Wang, P.; Wang, C.; Miao, L.; Ao, Y. et al. Interpretation of the disparity in harvesting efficiency of different types of Microcystis aeruginosa using polyethylenimine (PEI)-coated magnetic nanoparticles. Algal Research 2018, 29, 257-265, https://doi.org/10.1016/j.algal.2017.10.020.

75. Zhao, Y.; Liang, W.; Liu, L.; Li, F.; Fan, Q.; Sun, X. Harvesting Chlorella vulgaris by magnetic flocculation using Fe3O4 coating with poly aluminium chloride and polyacrylamide. Bio resource Technology 2015, 198, 789-796, https://doi.org/10.1016/j.biortech.2015.09.087.

76. Zhao, Y.; Wang, X.; Jiang, X.; Fan, Q.; Li, X.; Jiao, L.; Liang, W. Harvesting of Chlorella vulgaris using $\mathrm{Fe}_{3} \mathrm{O}_{4}$ coated with modified plant polyphenol. Environmental Science and Pollution Research 2018, 25, 26246-26258, https://doi.org/10.1007/s11356-018-2677-8.

77. Ganesan, R.; Manigandan, S.; Samuel, M.; Shanmuganathan, R.; Brindhadevi, K.; Lan Chi, N. et al. A review on prospective production of biofuel from microalgae. Biotechnology Reports 2020, 27, e00509, https://doi.org/10.1016/j.btre.2020.e00509.

78. Mona, S., Kumar, S. S., Kumar, V., Parveen, K., Saini, N., Deepak, B., Pugazhendhi, A. Green technology for sustainable bio hydrogen production (waste to energy): A review. Science of the Total Environment 2020, 728, 138481, https://doi.org/10.1016/j.scitotenv.2020.138481.

79. Ewurum, C. Techno-economic analysis of micro-algae Bio-jet fuel production processes (Ph.D thesis). Department of Chemical and Environmental engineering, University of Nottingham 2018. http://eprints.nottingham.ac.uk/55826/1/Chioma\%20Ewurum\%20thesis-minor\%20correction.pdf.

80. Ghirardi, M. L. Implementation of photo biological $\mathrm{H}_{2}$ production: the $\mathrm{O}_{2}$ sensitivity of hydrogenases. Photosynthesis Research 2015, 125, 383-393, https://doi.org/10.1007/s11120-015-0158-1.

81. Bayro-Kaiser, V.; Nelson, N. Micro algal hydrogen production: prospects of an essential technology for a clean and sustainable energy economy. Photosynthesis Research 2017, 49-62, https://doi.org/10.1007/s11120-017-0350-6.

82. Sosa-Hernández, J.; Romero-Castillo, K.; Parra-Arroyo, L.; Aguilar-Aguila-Isaías, M.; García-Reyes, I.; Ahmed, I. et al. Mexican Microalgae Biodiversity and State-Of-The-Art Extraction Strategies to Meet Sustainable Circular Economy Challenges: High-Value Compounds and Their Applied Perspectives. Marine Drugs 2019, 17, 174, https://doi.org/10.3390/md17030174.

83. Grosso, C.; Valentão, P.; Ferreres, F.; Andrade, P. Alternative and Efficient Extraction Methods for MarineDerived Compounds. Marine Drugs 2015, 13, 3182-3230, https://doi.org/10.3390/md13053182.

84. Cikoš, A.; Jokić, S.; Šubarić, D.; Jerković, I. Overview on the Application of Modern Methods for the Extraction of Bioactive Compounds from Marine Macroalgae. Marine Drugs 2018, 16, 348, https://doi.org/10.3390/md16100348.

85. Flórez-Fernández, N.; González Muñoz, M. Ultrasound-Assisted Extraction of Bioactive Carbohydrates. Water Extraction of Bioactive Compounds 2017, 317-331, https://doi.org/10.1016/b978-0-12-8093801.00012-7.

86. Mubarak .M; Shaija A.; Suchithra T.V. A review on the extraction of lipid from microalgae for biodiesel production. Algal Research 2015, 7, 117-123, https://doi.org/10.1016/j.algal.2014.10.008.

87. Gao, L.; Sun, J.; Xu, W.; Xiao, G. Catalytic pyrolysis of natural algae over Mg-Al layered double oxides/ZSM-5 (MgAl-LDO/ZSM-5) for producing bio-oil with low nitrogen content. Bioresource Technology 2017, 225, 293-298, https://doi.org/10.1016/j.biortech.2016.11.077. 
88. Sotoudehniakarani, F.; Alayat, A.; McDonald, A. Characterization and comparison of pyrolysis products from fast pyrolysis of commercial Chlorella vulgaris and cultivated microalgae. Journal of Analytical and Applied Pyrolysis 2019, 139, 258-273, https://doi.org/10.1016/j.jaap.2019.02.014.

89. Ansah, E.; Wang, L.; Zhang, B.; Shahbazi, A. Catalytic pyrolysis of raw and hydrothermally carbonized Chlamydomonas debaryana microalgae for denitrogenation and production of aromatic hydrocarbons. Fuel 2018, 228, 234-242, https://doi.org/10.1016/j.fuel.2018.04.163.

90. Aramkitphotha, S.; Tanatavikorn, H.; Yenyuak, C.; Vitidsant, T. Low sulphur fuel oil from blends of microalgae pyrolysis oil and used lubricating oil: Properties and economic evaluation. Sustainable Energy Technologies and Assessments 2019, 31, 339-346, https://doi.org/10.1016/j.seta.2018.12.019.

91. Zainan, N.; Srivatsa, S.; Li, F.; Bhattacharya, S. Quality of bio-oil from catalytic pyrolysis of microalgae Chlorella vulgaris. Fuel 2018, 223, 12-19, https://doi.org/10.1016/j.fuel.2018.02.166.

92. Anand, V.; Gautam, R.; Vinu, R. Non-catalytic and catalytic fast pyrolysis of Schizochytrium limacinum microalga. Fuel 2017, 205, 1-10, https://doi.org/10.1016/j.fuel.2017.05.049.

93. Gong, X.; Zhang, B.; Zhang, Y.; Huang, Y.; Xu, M. Investigation on Pyrolysis of Low Lipid Microalgae Chlorella vulgaris and Dunaliella salina. Energy and Fuels 2013, 28, 95-103, https://doi.org/10.1021/ef401500z.

94. Ceylan, S.; Kazan, D. Pyrolysis kinetics and thermal characteristics of microalgae Nannochloropsis oculata and Tetraselmis sp. Bioresource Technology 2015, 187, 1-5, https://doi.org/10.1016/j.biortech.2015.03.081.

95. Ma, C.; Geng, J.; Zhang, D.; Ning, X. Non-catalytic and catalytic pyrolysis of Ulva prolifera macro algae for production of quality bio-oil. Journal of the Energy Institute 2020, 93, 303-311, https://doi.org/10.1016/j.joei.2019.03.001.

96. Abd Rahman, N.; Fermoso, J.; Sanna, A. Stability of Li-LSX Zeolite in the Catalytic Pyrolysis of Non-Treated and Acid Pre-Treated Isochrysis sp. Microalgae. Energies 2020, 13, 959, https://doi.org/10.3390/en13040959.

97. Ly, H.; Choi, J.; Woo, H.; Kim, S.; Kim, J. Upgrading bio-oil by catalytic fast pyrolysis of acid-washed Saccharina japonica alga in a fluidized-bed reactor. Renewable Energy 2019, 133, 11-22, https://doi.org/10.1016/j.renene.2018.09.103.

98. Jafarian, S.; Tavasoli, A. A comparative study on the quality of bioproducts derived from catalytic pyrolysis of green microalgae Spirulina (Arthrospira) plantensis over transition metals supported on HMS-ZSM5 composite. International Journal of Hydrogen Energy 2018, 43, 19902-19917, https://doi.org/10.1016/j.ijhydene.2018.08.171.

99. Bi, Z.; Zhang, J.; Zhu, Z.; Liang, Y.; Wiltowski, T. Generating biocrude from partially defatted Cryptococcus curvatus yeast residues through catalytic hydrothermal liquefaction. Applied Energy 2018, 209, 435-444, https://doi.org/10.1016/j.apenergy.2017.11.031.

100.Flórez, N.; Conde, E.; Domínguez, H. Microwave assisted water extraction of plant compounds. Journal of Chemical Technology and Biotechnology 2014, 90, 590-607, https://doi.org/10.1002/jctb.4519.

101. García, J.; de Vicente, M.; Galán, B. Microalgae, old sustainable food and fashion nutraceuticals. Microbial Biotechnology 2017, 10, 1017-1024, https://doi.org/10.1111/1751-7915.12800.

102.Tarazona-Janampa, U.; Cembella, A.; Pelayo-Zárate, M.; Pajares, S.; Márquez-Valdelamar, L.; Okolodkov, Y. et al. Associated Bacteria and Their Effects on Growth and Toxigenicity of the Dinoflagellate Prorocentrum lima species Complex from Epibenthic Substrates Along Mexican Coasts. Frontiers in Marine Science 2020, 7, https://doi.org/10.3389/fmars.2020.00569.

103.Chen, H.; Wang, X.; Wang, Q. Micro algal biofuels in China: The past, progress and prospects. GCB Bioenergy 2020, 12, 1044-1065, https://doi.org/10.1111/gcbb.12741.

104. Saifuddin, N.; Priatharsini, P. Developments in Bio-hydrogen Production from Algae: A Review. Research Journal of Applied Sciences, Engineering and Technology 2016, 12, 968-982, https://doi.org/10.19026/rjaset.12.2815.

105.Lin, K.; Lin, Y.; Hsiao, Y. Microwave plasma studies of Spirulina algae pyrolysis with relevance to hydrogen production. Energy 2014, 64, 567-574, https://doi.org/10.1016/j.energy.2013.09.055.

106.Wei, L.; Yi, J.; Wang, L.; Huang, T.; Gao, F.; Wang, Q.; Ma, W. Light Intensity is Important for Hydrogen Production in $\mathrm{NaHSO}_{3}$-Treated Chlamydomonas reinhardtii. Plant and Cell Physiology 2017, pcw216, https://doi.org/10.1093/pcp/pcw216.

107.Wei, L.; Fan, B.; Yi, J.; Xie, T.; Liu, K.; Ma, W. Mechanistic insights into $\mathrm{pH}$-dependent $\mathrm{H}_{2}$ photo production in bisulfite-treated Chlamydomonas cells. Biotechnology for Biofuels 2020, 13, https://doi.org/10.1186/s13068-020-01704-0. 
108.Xiong, W.; Zhao, X.; Zhu, G.; Shao, C.; Li, Y.; Ma, W. et al. Silicification-Induced Cell Aggregation for the Sustainable Production of H2under Aerobic Conditions. Angewandte Chemie International Edition 2015, 54, 11961-11965, https://doi.org/10.1002/anie.201504634.

109.Giordano M.; Wang Q.; Microalgae for Industrial Purposes, In: Vaz Jr. S. (eds) Biomass and Green Chemistry, Springer, Cham. 2018, 133-167, https://doi.org/10.1007/978-3-319-66736-2_6.

110.Miao, H.; Wang, S.; Zhao, M.; Huang, Z.; Ren, H.; Yan, Q.; Ruan, W. Codigestion of Taihu blue algae with swine manure for biogas production. Energy Conversion and Management 2014, 77, 643-649, https://doi.org/10.1016/j.enconman.2013.10.025.

111.Lin, R.; Cheng, J.; Murphy, J. Inhibition of thermochemical treatment on biological hydrogen and methane co-production from algae-derived glucose/glycine. Energy Conversion and Management 2018, 158, 201-209, https://doi.org/10.1016/j.enconman.2017.12.052.

112.Ding, L.; Chan Gutierrez, E.; Cheng, J.; Xia, A.; O'Shea, R.; Guneratnam, A.; Murphy, J. Assessment of continuous fermentative hydrogen and methane co-production using macro- and micro-algae with increasing organic loading rate. Energy 2018, 151, 760-770, https://doi.org/10.1016/j.energy.2018.03.103.

113.Xu, J.; Zhao, Y.; Zhao, G.; Zhang, H. Nutrient removal and biogas upgrading by integrating freshwater algae cultivation with piggery anaerobic digestate liquid treatment. Applied Microbiology and Biotechnology 2015, 99, 6493-6501, https://doi.org/10.1007/s00253-015-6537-x.

114. Sharma, P.; Sharma, N. Industrial and Biotechnological Applications of Algae: A Review. Journal of Advances in Plant Biology 2017, 1, 1-25, https://doi.org/10.14302/issn.2638-4469.japb-17-1534.

115.Wang, M.; Lee, E.; Dilbeck, M.; Liebelt, M.; Zhang, Q.; Ergas, S. Thermal pre-treatment of microalgae for biomethane production: experimental studies, kinetics and energy analysis. Journal of Chemical Technology and Biotechnology 2016, 92, 399-407, https://doi.org/10.1002/jctb.5018.

116.Chen, H.; Zhang, Y.; He, C.; Wang, Q. Ca2+ Signal Transduction Related to Neutral Lipid Synthesis in an Oil-Producing Green Alga Chlorella sp. C2. Plant and Cell Physiology 2014, 55, 634-644, https://doi.org/10.1093/pcp/pcu015.

117.Bibi, R.; Ahmad, Z.; Imran, M.; Hussain, S.; Ditta, A.; Mahmood, S.; Khalid, A. Algal bioethanol production technology: A trend towards sustainable development. Renewable and Sustainable Energy Reviews 2017, 71, 976-985, https://doi.org/10.1016/j.rser.2016.12.126.

118.de Farias Silva, C.; Bertucco, A. Bioethanol from microalgae and cyanobacteria: A review and technological outlook. Process Biochemistry 2016, 51, 1833-1842, https://doi.org/10.1016/j.procbio.2016.02.016.

119. Ariede, M.; Candido, T.; Jacome, A.; Velasco, M.; de Carvalho, J.; Baby, A. Cosmetic attributes of algae - A review. Algal Research 2017, 25, 483-487, https://doi.org/10.1016/j.algal.2017.05.019.

120.Fick, G.; Mirgaux, O.; Neau, P.; Patisson, F. Using Biomass for Pig Iron Production: A Technical, Environmental and Economical Assessment. Waste and Biomass Valorization 2013, 5, 3-55, https://doi.org/10.1007/s12649-013-9223-1.

121. Rathore, D.; Singh, A.; Dahiya, D.; Singh Nigam, P. Sustainability of bio hydrogen as fuel: Present scenario and future perspective. AIMS Energy 2019, 7, 1-19, https://doi.org/10.3934/energy.2019.1.1.

122.Dahlgren, S. Biogas-based fuels as renewable energy in the transport sector: an overview of the potential of using CBG, LBG and other vehicle fuels produced from biogas. Biofuels 2020, 1-13, https://doi.org/10.1080/17597269.2020.1821571.

123.Rahman, S.; Masdar, M.; Rosli, M.; Majlan, E.; Husaini, T. Overview of Biohydrogen Production Technologies and Application in Fuel Cell. American Journal of Chemistry 2015, 5, 13-23, https://doi.org/10.5923/c.chemistry.201501.03.

124.No, S. Application of bioethanol to advanced CI engines; dual fuel and RCCI combustion modes - a review. International Journal of Green Energy 2019, 16, 1105-1130, https://doi.org/10.1080/15435075.2019.1653878.

125.Stead, C., Wadud, Z., Nash, C., Li, H. Introduction of Biodiesel to Rail Transport: Lessons from the Road Sector. Sustainability 2019, 11, 904, https://doi.org/10.3390/su11030904.

126. Maiorova, A.; Vasilev, A.; Chelebyan, O. Biofuels in Aircraft Engines. In Biofuels - Status and Perspective 2015, Open access peer-reviewed chapter, https://doi.org/10.5772/59871.

127.Li, Y.; Tian, G.; Xu, H. Application of Biodiesel in Automotive Diesel Engines. In Biodiesel - Feedstocks, Production and Applications 2012, Open access peer-reviewed chapter, https://doi.org/10.5772/53222.

128.Ru, I.; Sung, Y.; Jusoh, M.; Wahid, M.; Nagappan, T. Chlorella vulgaris: a perspective on its potential for combining high biomass with high value bio products. Applied Phycology 2020, 1, 2-11, https://doi.org/10.1080/26388081.2020.1715256. 
129.Kumar, G.; Shekh, A.; Jakhu, S.; Sharma, Y.; Kapoor, R.; Sharma, T. Bioengineering of Microalgae: Recent Advances, Perspectives, and Regulatory Challenges for Industrial Application. Frontiers in Bioengineering and Biotechnology 2020, 8, https://doi.org/10.3389/fbioe.2020.00914.

130.Koyande, A.; Chew, K.; Rambabu, K.; Tao, Y.; Chu, D.; Show, P. Microalgae: A potential alternative to health supplementation for humans. Food Science and Human Wellness 2019, 8, 16-24, https://doi.org/10.1016/j.fshw.2019.03.001.

131.Nilesh Hemantkumar, J.; Ilza Rahimbhai, M. (Microalgae and Its Use in Nutraceuticals and Food Supplements. Microalgae - From Physiology to Application 2020, https://doi.org/10.5772/intechopen.90143.

132.Sathasivam, R.; Radhakrishnan, R.; Hashem, A.; Abd-Allah, E. Microalgae metabolites: A rich source for food and medicine. Saudi Journal of Biological Sciences 2019, 26, 709-722, https://doi.org/10.1016/j.sjbs.2017.11.003.

133.Lourenço-Lopes, C.; Garcia-Oliveira, P.; Carpena, M.; Fraga-Corral, M.; Jimenez-Lopez, C.; Pereira, A. et al. Scientific Approaches on Extraction, Purification and Stability for the Commercialization of Fucoxanthin Recovered from Brown Algae. Foods 2020, 9, 1113, https://doi.org/10.3390/foods9081113.

134.Wang, Y.; Xing, M.; Cao, Q.; Ji, A.; Liang, H.; Song, S. Biological activities of Fucoidan and the factors mediating its therapeutic effects: A Review of Recent Studies. Marine Drugs 2019, 17, 183, https://doi.org/10.3390/md17030183.

135.Zhang, H.; Tang, Y.; Zhang, Y.; Zhang, S.; Qu, J.; Wang, X. et al. Fucoxanthin: A Promising Medicinal and Nutritional Ingredient. Evidence-Based Complementary and Alternative Medicine 2015, 1-10, https://doi.org/10.1155/2015/723515.

136. Mondal, A.; Bose, S.; Banerjee, S.; Patra, J.; Malik, J.; Mandal, S. et al. Marine Cyanobacteria and Microalgae Metabolites-a Rich Source of Potential Anticancer Drugs. Marine Drugs 2020, 18, 476, https://doi.org/10.3390/md18090476.

137. Salehzadeh, A.; Delshadpour, F. S.; Seyyed, A, S. S. Cytotoxicity Effect and Changes in the Expression of Caspase-9 Gene in Breast Cancer Cell Line (MCF-7) Treated with the Extract of Oscillatoria Cyanobacteria. Qom Univ Med Sci J 2018, 12, 26-34, https://doi.org/10.29252/qums.12.1.26.

138. Shishido, T.; Popin, R.; Jokela, J.; Wahlsten, M.; Fiore, M.; Fewer, D. et al. Dereplication of Natural Products with Antimicrobial and Anticancer Activity from Brazilian Cyanobacteria. Toxins 2019, 12, 12, https://doi.org/10.3390/toxins12010012.

139.Patel, A.; Mikes, F.; Matsakas, L. An Overview of Current Pre-treatment Methods Used to Improve Lipid Extraction from Oleaginous Micro-Organisms. Molecules 2018, 23, 1562, https://doi.org/10.3390/molecules23071562.

140.Shokravi, Z.; Shokravi, H.; Chyuan, O. H.; Lau, W. J.; Koloor, S. S. R.; Petru, M.; Ismail, A. F. Improving 'lipid productivity' in microalgae by bilateral enhancement of biomass and lipid contents: a review, Sustainability 2020, 12, 9083, https://doi.org/10.3390/su12219083.

141.Wang, Q.; Oshita, K.; Takaoka, M. Effective lipid extraction from undewatered microalgae liquid using subcritical dimethyl ether. Biotechnol Biofuels 2021, 14, 17, https://doi.org/10.1186/s13068-020-01871-0.

142.Win, T.; Barone, G.; Secundo, F.; Fu, P. Algal Bio fertilizers and Plant Growth Stimulants for Sustainable Agriculture. Industrial Biotechnology 2018, 14, 203-211, https://doi.org/10.1089/ind.2018.0010.

143.Ullmann, J.; Grimm, D. Algae and their potential for a future bioeconomy, landless food production, and the socio-economic impact of an algae industry. Org. Agr. 2021, https://doi.org/10.1007/s13165-020-00337-9.

144.Camacho, F.; Macedo, A.; Malcata, F. Potential Industrial Applications and Commercialization of Microalgae in the Functional Food and Feed Industries: A Short Review. Marine Drugs 2019, 17, 312, https://doi.org/10.3390/md17060312. 